\title{
Local nutrient regimes determine site-specific environmental triggers of cyanobacterial and microcystin variability in urban lakes
}

\author{
S. C. Sinang ${ }^{1, *}$, E. S. Reichwaldt ${ }^{1}$, and A. Ghadouani ${ }^{1}$ \\ ${ }^{1}$ Aquatic Ecology and Ecosystem Studies, School of Civil, Environmental and Mining Engineering, The University of \\ Western Australia, 35 Stirling Highway, M015, Crawley, WA 6009, Western Australia, Australia \\ * present address: Faculty of Science and Mathematics, Sultan Idris Education University, 35900 Tanjong Malim, \\ Perak, Malaysia
}

Correspondence to: A. Ghadouani (anas.ghadouani@uwa.edu.au)

Received: 7 August 2014 - Published in Hydrol. Earth Syst. Sci. Discuss.: 10 October 2014

Revised: 25 March 2015 - Accepted: 9 April 2015 - Published: 7 May 2015

\begin{abstract}
Toxic cyanobacterial blooms in urban lakes present serious health hazards to humans and animals and require effective management strategies. Managing such blooms requires a sufficient understanding of the controlling environmental factors. A range of them has been proposed in the literature as potential triggers for cyanobacterial biomass development and cyanotoxin (e.g. microcystin) production in freshwater systems. However, the environmental triggers of cyanobacteria and microcystin variability remain a subject of debate due to contrasting findings. This issue has raised the question of whether the relevance of environmental triggers may depend on site-specific combinations of environmental factors. In this study, we investigated the site-specificity of environmental triggers for cyanobacterial bloom and microcystin dynamics in three urban lakes in Western Australia. Our study suggests that cyanobacterial biomass, cyanobacterial dominance and cyanobacterial microcystin content variability were significantly correlated to phosphorus and iron concentrations. However, the correlations were different between lakes, thus suggesting a sitespecific effect of these environmental factors. The discrepancies in the correlations could be explained by differences in local nutrient concentration. For instance, we found no correlation between cyanobacterial fraction and total phosphorous (TP) in the lake with the highest TP concentration, while correlations were significant and negative in the other two lakes. In addition, our study indicates that the difference of the correlation between total iron (TFe) and the cyanobacterial fraction between lakes might have been a consequence of differences in the cyanobacterial community structure, specifically
\end{abstract}

the presence or absence of nitrogen-fixing species. In conclusion, our study suggests that identification of significant environmental factors under site-specific conditions is an important strategy to enhance successful outcomes in cyanobacterial bloom control measures.

\section{Introduction}

Urban lakes often serve as recreational spaces for communities and habitats for wildlife (Yan et al., 2012; Liu, 2014). To date, many urban lakes continue to deteriorate due to increased anthropogenic activities and often face water quality problems including toxic cyanobacteria blooms (PinedaMendoza et al., 2012; Reichwaldt and Ghadouani, 2012; Lei et al., 2014; Sun et al., 2014; Zhang et al., 2014). This issue has received great attention from water authorities worldwide as it presents health hazards to humans and animals who either directly or indirectly received services provided by urban lakes (O'Bannon et al., 2014; Rastogi et al., 2014; Waajen et al., 2014). The management of toxic cyanobacterial blooms is often challenging due to the variability in cyanobacteria biomass and microcystins (Rolland et al., 2013; Carey et al., 2014). In addition, microcystin production by cyanobacteria is a complex issue that might depend on their competition with other phytoplankton (e.g. Huisman and Hulot, 2005; Jang et al., 2006). From these earlier studies it can be concluded that the toxin concentration produced by a certain cyanobacterial biomass level might differ, depending on the level of competition (i.e. cyanobacterial frac- 
tion) indicating that management should consider biomass and cyanobacterial fractions concurrently.

Cyanobacterial biomass and the amount of microcystins being produced during toxic cyanobacterial blooms can vary significantly on a spatial basis within and between lakes (Reichwaldt et al., 2013; Sinang et al., 2013; Thi Thuy et al., 2014; Waajen et al., 2014). Past studies have found large variations in the percentage of potentially toxic cyanobacteria and in the microcystin concentration between spatially isolated phytoplankton communities (Sitoki et al., 2012; Li et al., 2014). Furthermore, it was reported that the variability of cyanobacterial biomass in lakes only explained a small fraction of the variability in microcystin concentration (Sinang et al., 2013; Eva and Lindsay, 2014). These findings highlight the importance of fully understanding the roles of environmental factors controlling both the cyanobacteria and the microcystin variability.

It has been suggested that cyanobacterial biomass and microcystin variability largely depends upon physical, chemical and biological properties of the water bodies (Engström-Öst et al., 2013; Lehman et al., 2013; Paerl and Otten, 2013; Ruiz et al., 2013). A range of environmental factors, including nitrogen and phosphorus concentrations (Schindler, 2012; Srivastava et al., 2012; Chaffin and Bridgeman, 2014; Van de Waal et al., 2014), TN : TP ratio (Smith, 1983; Wang et al., 2010b; Van de Waal et al., 2014), temperature (Davis et al., 2009; Rolland et al., 2013), salinity (Tonk et al., 2007), and iron concentration (Ame and Wunderlin, 2005; Nagai et al., 2007; Wang et al., 2010a) have been shown to have pronounced effects on cyanobacterial biomass, cyanobacterial dominance and microcystin production. Nevertheless, the results between studies differ, and there is no clear understanding of the roles of these environmental factors as the triggers of cyanobacterial bloom development and microcystin production. Furthermore, the occurrence of cyanobacterial toxins in a system is the result of a complex interaction between abiotic and biotic factors, including the competition with other phytoplankton. It therefore remains an important challenge for bloom management to fully understand the mechanisms behind toxic cyanobacterial bloom development and the drivers for biomass development, cyanobacterial dominance (fraction) and toxin production. For instance, regardless of the fact that many studies suggest the important role of phosphorus, reduction of internal and external phosphorus concentration is not always successful in preventing the occurrence of toxic cyanobacterial blooms in water bodies (Lewis and Wurtsbaugh, 2008; Amano et al., 2010; Koreiviene et al., 2014).

By taking into account the contrasting findings of earlier studies, including inconsistent outcomes of nutrient reduction strategies, we suggest that the main environmental triggers of cyanobacterial and microcystin variability may vary between water bodies due to the complex, lake-specific interplay of environmental conditions. Therefore, the main objective of this study was to investigate the site-specificity of en-

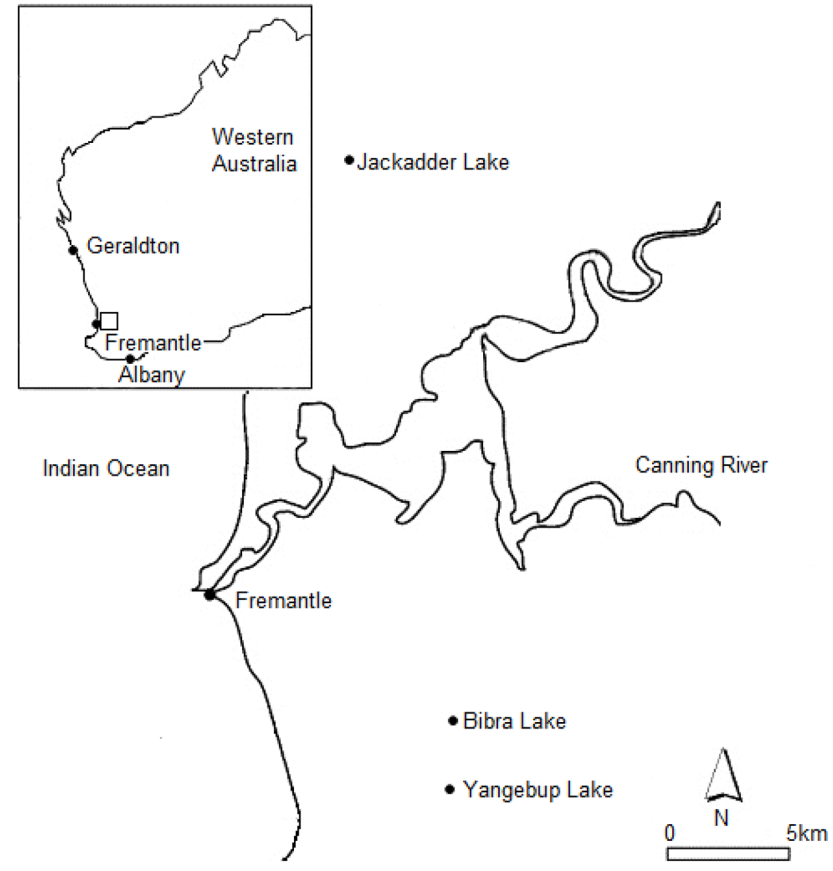

Figure 1. The locations of three studied lakes on Swan Coastal Plain.

vironmental triggers for cyanobacterial biomass and microcystin variability in a local urban lake system. More specifically, the objectives were to (1) determine the variability of cyanobacterial biomass and microcystin concentration in a set of local urban lakes, and (2) identify the site-specific relationships between environmental factors and cyanobacterial or microcystin dynamics.

\section{Material and methods}

\subsection{Study lakes}

This study was carried out in Jackadder Lake $\left(31^{\circ} 54^{\prime} 30 \mathrm{~S}\right.$, $\left.115^{\circ} 47^{\prime} 36 \mathrm{E}\right)$, Bibra Lake $\left(32^{\circ} 5^{\prime} 25 \mathrm{~S}, 115^{\circ} 49^{\prime} 16 \mathrm{E}\right)$ and Yangebup Lake $\left(32^{\circ} 6^{\prime} 56 \mathrm{~S}, 115^{\circ} 49^{\prime} 33 \mathrm{E}\right)$ located on the Swan Coastal Plain, Western Australia (Fig. 1). Sampling was carried out between January and March 2010. These lakes are shallow with mean depth of $2.1,1.1$, and $2.5 \mathrm{~m}$ for Jackadder Lake, Bibra Lake and Yangebup Lake, respectively. Jackadder Lake and Yangebup Lake are permanent lakes while Bibra Lake is subjected to seasonal drying due to progressive decline in groundwater levels over the Jandakot Mound. Jackadder Lake has an area of 7.18 ha, is surrounded by 6.6 ha of parkland and is draining a 152 ha catchment area (Arnold, 1990; Woodward, 2008). Water levels in Jackadder Lake are maintained by the input of surface runoff via 10 drain inlets (Rajah, 1991, as cited in Kemp, 2009). Jackadder Lake receives water from the Herdsman Lake catchment area and Osborne Park main drain during dry summers (De- 
partment of Planning, 2010). Bibra Lake has a size of 135 ha with an open water area of approximately 100 ha (Strategen, 2009) and is located within a 250 ha catchment are. This lake is surrounded by urban areas and a golf course and serves as habitat for many species of water birds (Kemp, 2009). Water enters Bibra Lake via direct rainfall recharge onto the lake surface or from surface runoff from the surrounding catchment (Strategen, 2009). Yangebup Lake has a total area of 90.5 ha with an open water area of approximately 68 ha, and is surrounded by residential, agriculture and industrial areas. Yangebup Lake is a groundwater through-flow wetland that accepts groundwater from the east and discharges groundwater to the west (Dunlop, 2008). Yangebup Lake receives urban runoff from three storm-water drains and additionally serves as a compensation basin for the South Jandakot drainage system with an approximate area of $200 \mathrm{~km}^{2}$. This includes receiving water from neighbouring Thomson Lake when it reaches its maximum water level. Once Yangebup Lake reaches its maximum allowable water level, water is pumped into nearby Cockburn Sound (Environmental Protection Authority, 1989). The hydrology of Jackadder, Bibra and Yangebup lakes is mainly affected by the strong seasonal rainfall pattern due to the Mediterranean climate. The region's mean annual rainfall is reported as $771.5 \mathrm{~mm}$ and monthly mean rainfall is $35.1,156.3,433.3$ and $144.2 \mathrm{~mm}$ during summer, autumn, winter and spring, respectively $(\mathrm{Bu}-$ reau of Meteorology, 2014). In response, the maximum water levels in all lakes occur in September and October, and the minimum water levels occur in March and April at the end of summer months (Davis et al., 1993). The region's mean maximum annual temperature is $24.5^{\circ} \mathrm{C}$ and monthly maximum temperatures are $30.9,25.4,18.0$ and $22.6^{\circ} \mathrm{C}$ during summer, autumn, winter and spring, respectively (Bureau of Meteorology, 2014). Prolonged stable thermal stratification is usually prevented in these lakes during summer due to continuous or intermittent wind mixing that creates a homogeneous environment throughout the water column (Davis et al., 1993; Arnold and Oldham, 1997).

These lakes were selected due to differences reported on physicochemical properties, levels of cyanobacterial biomass and microcystin concentration. Based on an earlier study conducted between November 2008 and July 2009 (Sinang et al., 2013), these lakes represent systems with low, medium and high cyanobacterial biomass and microcystin concentration. In this earlier study, the highest cyanobacterial biomass was reported as 28, 108, and $80 \mu \mathrm{g} \mathrm{chl} a \mathrm{~L}^{-1}$ in Jackadder, Bibra and Yangebup Lake, respectively. The highest cellular microcystin concentrations $\left(\mathrm{mg} \mathrm{g}^{-1}\right.$ cyanobacterial dry mass) was $4.8 \mathrm{mg} \mathrm{g}^{-1}$ in Jackadder Lake, $35 \mathrm{mg} \mathrm{g}^{-1}$ in Bibra Lake and $1.7 \mathrm{mg} \mathrm{g}^{-1}$ in Yangebup Lake (Sinang et al., 2013).

\subsection{Sampling and analyses}

The lakes were sampled twice a month between January and March 2010, leading to 6 sampling days. Three samples were

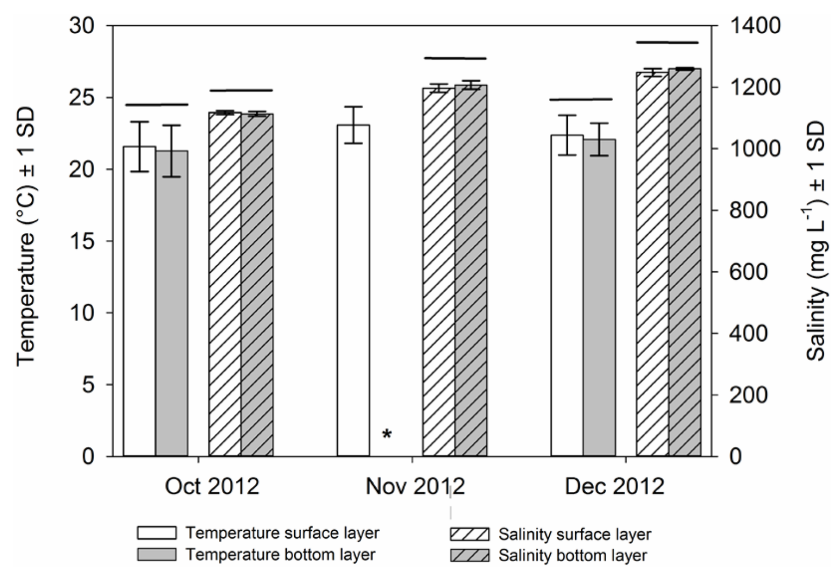

Figure 2. Temperature $\left({ }^{\circ} \mathrm{C}\right)$ and salinity $(\mathrm{ppm})$ in the surface and bottom layers measured at seven sites over three months in Lake Yangebup during a previous study in 2012. “*” indicates missing data; horizontal line indicates that no significant difference between layers were detected ( $t$-test) (from Song et al., 2015).

collected from the same three points at each lake on every sampling occasion. As Bibra Lake dried up in late February no samples were taken from this lake in March, leading to only 4 sampling days. On-site measurements and samples were taken from shore sites at a water depth of 0.6 to $1 \mathrm{~m}$. Temperature (Temp), $\mathrm{pH}$ and Salinity (Sal) were measured on-site with a WP-81 probe (TPS Pty Ltd) at a depth of $0.6 \mathrm{~m}$. Grab water samples for cyanobacteria, microcystin and total phosphorus quantification were taken from approximately $0.15 \mathrm{~m}$ below the surface to avoid surface scum. Although there was a slight difference in the depth from which the samples for the physicochemical and water samples were taken, this is not expected to influence the interpretation of the results, as earlier studies in these lakes indicated that the water bodies at these shallow shore sites are well mixed with respect to physicochemical conditions (Arnold and Oldham, 1997; Song et al., 2015) (Fig. 2). Water samples were stored immediately in glass bottles in the dark on ice. Variables analysed from these samples were total phosphorus (TP), total dissolved phosphorus (TDP), total iron (TFe), total dissolved iron (TDFe), total nitrogen (TN), total dissolved nitrogen (TDN), ammonium $\left(\mathrm{NH}_{4}^{+}\right)$, cyanobacterial biomass, total phytoplankton biomass, intracellular and extracellular microcystin fractions. Samples for dissolved nutrient analyses were pre-filtered with a $0.45 \mu \mathrm{m}$ syringe filter (Acrodisc, HT Tuffryn) before freezing at $-20^{\circ} \mathrm{C}$.

Surface water temperatures were between 19.9 and $28.7^{\circ} \mathrm{C}$ during the study period. However, the on-site measurements of surface water temperatures were dependent on the time of sampling and varied by up to $3.9^{\circ} \mathrm{C}$ over the course of a day. Therefore, maximum air temperature on each sampling day recorded by weather stations located nearest to the studied lakes was used as a substitute for surface water temperature in all analyses (Yen et al., 2007). 


\subsubsection{Nutrients and phytoplankton biomass}

TP and TDP concentrations were analysed using the ascorbic acid method, while TFe and TDFe concentrations were analysed with the phenanthroline method, according to standard methods (APHA, 1998). TN, TDN, and $\mathrm{NH}_{4}^{+}$were analysed at the South Coast Nutrients Analysis Laboratory, Albany, Western Australia with the standard colorimetric methods on a segmented flow auto-analyser (Alpkem, Wilsonville, OR, USA). Cyanobacterial and total phytoplankton chlorophyll $a$ were measured with a top-bench version of a FluoroProbe (bbe Moldaenke, Germany).The FluoroProbe measures chl $a$ fluorescence and differentiates four groups of phytoplankton (chlorophytes, cryptophytes, diatoms and cyanobacteria) by their specific fluorescence emission spectrum (Beutler et al., 2002). The fluorescence is used to calculate total biomass of each phytoplankton group that is expressed as chl $a$ concentration equivalents ( $\mu \mathrm{g} \mathrm{chl} a \mathrm{~L}^{-1}$ ) (Beutler et al., 2002; Ghadouani and Smith, 2005). FluoroProbe chl $a$ measurements were validated against chl $a$ data of samples extracted according to standard methods (APHA, 1998) (linear regression analysis: $\left.R^{2}=0.94, N=32, p<0.05\right)$. In our study, chl $a$ fluorescence as measured by FluoroProbe was used as a proxy for cyanobacterial biomass (Geis et al., 2000; Eisentraeger et al., 2003).

For quantification of cyanobacterial biomass and to separate the intracellular from the dissolved microcystin fraction, water samples were filtered through pre-combusted and preweighed $47 \mathrm{~mm}$ GF/C filter papers. Filter papers containing particulate organic matter were dried for $24 \mathrm{~h}$ at $60^{\circ} \mathrm{C}$ and re-weighed to obtain total dry weight (Harada et al., 1999). These filter papers were then moistened with Milli-Q water and kept frozen $\left(\right.$ at $-20^{\circ} \mathrm{C}$ ) until intracellular microcystin extraction. As we were interested in the microcystin concentration per unit cyanobacterial dry mass, cyanobacterial dry mass was calculated from the total dry mass (from the filters) by adjusting it to the percentage of cyanobacteria measured with the FluoroProbe. Cyanobacterial dry mass was only used for microcystin quantification.

Water samples collected for cyanobacterial identification and enumeration were preserved with acidic Lugol's iodine solution $\left(5 \mathrm{~g} \mathrm{I}_{2}+10 \mathrm{~g} \mathrm{KI}, 20 \mathrm{~mL}\right.$ distilled water and $50 \mathrm{~mL}$ of $10 \%$ acetic acid) and cyanobacteria were identified to the genus level using phytoplankton taxonomic guideline (Komarek and Hauer, 2011). The relative abundance of each cyanobacterial genera (cells or colonies $\mathrm{mL}^{-1}$ ) was determined from $10-50 \mathrm{~mL}$ of sample using an inverse microscope (Utermöhl, 1958) and converted into biovolume per $\mathrm{mL}\left(\mu \mathrm{m}^{3} \mathrm{~mL}^{-1}\right)$ by multiplying the mean cell or colony biovolume $\left(\mu \mathrm{m}^{3}\right)$ with the total cells or colonies per millilitre (cells or colonies $\mathrm{mL}^{-1}$ ). Mean cell or colony biovolume for each cyanobacterial genus was calculated by finding the geometric figure that best approximated the shape of each genera, and by measuring the dimension of 20 individual cells or colonies (Hillebrand et al., 1999). A minimum of 200 cells or colonies of the most abundant cyanobacteria were counted for each sample. Different cyanobacterial species within each genus can vary in size by several orders of magnitude. However, as we measured the mean biovolume of each cyanobacterial genus, differences in sizes between species are evened out as a larger mean is expected, if larger species are more abundant and vice versa. The calculated mean biovolume of each cyanobacterial genus was used to compute the dominant cyanobacteria genera in the studied lakes.

\subsubsection{Microcystin extraction and quantification}

Filters were freeze-thawed twice to break the cells prior to methanol extraction (Lawton et al., 1994). Filters were placed into centrifuge tubes and $5 \mathrm{~mL}$ of $75 \%$ methanolwater $(v / v)$ was added. Filters were sonicated on ice for $25 \mathrm{~min}$, followed by gentle shaking for another $25 \mathrm{~min}$. The extracts were then centrifuged at $3273 \mathrm{~g}$ (Beckman and Coulter, Allegra X-12 Series) for $10 \mathrm{~min}$ at room temperature. Extracts were carefully transferred into conical flasks, and two more extractions were done per filter. All three extracts were pooled and diluted with Milli-Q to $20 \%$ methanol $(v / v)$.

Intracellular microcystin extracts and the pre-filtered water containing dissolved (extracellular) microcystin were subjected to solid-phase extraction (SPE) (Waters Oasis HLB) for clean-up and concentration with a loading speed of $<10 \mathrm{~mL} \mathrm{~min}^{-1}$. SPE cartridges were then rinsed with $10 \mathrm{~mL}$ of 10,20 and $30 \%$ methanol-water $(v / v)$, before microcystin was eluted with acidified methanol $(0.1 \% \quad v / v$ trifluoroacetic acid (TFA)) and evaporated with nitrogen gas at $40{ }^{\circ} \mathrm{C}$. Finally, samples were re-dissolved in $30 \%$ acetonitrile and analysed with high-performance liquid chromatography (HPLC) by using the Alliance 2695 (Waters, Australia) with a PDA detector (1.2 nm resolution) and an Atlantis T3 $3 \mu \mathrm{m}$ column $(4.6 \times 150 \mathrm{~mm}$ i.d. $)$. Mobile phases used were acidified acetonitrile ( $0.05 \% v / v$ TFA) and acidified Milli-Q water $(0.05 \% v / v$ TFA). Microcystin peaks were separated using a linear gradient as described in Lawton et al. (1994) but with a maximum acetonitrile concentration of $100 \%$ and a run time of $37 \mathrm{~min}$. Column temperature was maintained at $37.5 \pm 2.5^{\circ} \mathrm{C}$. The limit of detection per microcystin peak was $1.12 \mathrm{ng}$. Microcystin variants were identified based upon their typical absorption spectrum detected by PDA detector at $238 \mathrm{~nm}$ (Meriluoto and Codd, 2005). Commercially available microcystin-LR standard (Sapphire Bioscience, Australia; purity $\geq 95 \%$ ) was used to quantify microcystin concentrations. Throughout this paper we refer to the total concentration of microcystin variants per sample as microcystin concentration.

In this study, cellular (intracellular) microcystin concentration was expressed as $\mu \mathrm{g}$ microcystin-LR mass equivalents per gram cyanobacterial dry mass to illustrate cyanobacterial microcystin content. Extracellular microcystin was expressed as the fraction of extracellular microcystin concentration per total microcystin concentration to allow the quan- 
tification of the proportion of microcystin released into the water column in comparison to the total microcystin being produced.

\subsection{Data processing and statistical analyses}

Differences in physicochemical factors, cyanobacterial biomass and microcystin between lakes were analysed with one-way ANOVA (SPSS 17.0) with post hoc test (Least Significance Difference; LSD) as all assumptions for an ANOVA were met (homogeneity of variances, normality). For the descriptive phase, bivariate correlation analysis (Pearson's) was carried out to identify the environmental variables which significantly correlate with cyanobacterial fraction, cyanobacterial biomass, cellular microcystin concentration and extracellular microcystin fraction (SPSS 21.0). We used linear mixed models to identify correlations between environmental variables and cyanobacterial fraction, cyanobacterial biomass, cellular microcystin concentration and extracellular microcystin fraction in each lake using sampling site and sampling date as random factors, and for all lakes combined adding lake as random factor (SPSS 21.0). All dependent variables were $\ln$ transformed. As extracellular microcystins were only detected in 5 out of 12 samples in Bibra Lake, this resulted in only 5 data points for this dependent variable in Bibra Lake, making the calculation of linear mixed models for this explanatory variable impossible. Two redundancy analyses (RDA) were calculated to identify the best combination of variables to explain the variability of intracellular microcystin concentration, extracellular microcystin fraction and either cyanobacterial fraction or cyanobacterial biomass ( $\mathrm{R}$ version 2.15.1) for each lake. Canonical ordination (999 permutations) with forward selection was computed with standardised explanatory and response variables. All data was $\ln$ transformed to meet the assumption of normality. RDA analysis on Bibra Lake was conducted without the inclusion of $\mathrm{pH}$ and temperature due to an inadequate number of data points (residual d.f. $<0$ ). In all analyses, results were considered significant at $p<0.05$, unless stated differently.

\section{Results}

\subsection{Physical and chemical characteristics of studied lakes}

On the sampling days, mean $\mathrm{pH}$ fluctuated between 8.2 and 9.2 (Fig. 3a) and mean air temperature (Fig. 3b) ranged from 27 to $43^{\circ} \mathrm{C}$ in all lakes. Salinity in Jackadder and Yangebup was mostly below $1.0 \mathrm{ppk}$ and much lower than in Bibra Lake (Fig. 3c). The sharp increase in salinity in Bibra Lake was probably due to the decreasing water level as the lake dried up by end of February. Nutrient concentrations varied on a temporal basis within lakes and spatially between lakes. Phosphorus concentrations were higher in Bibra Lake than in Jackadder and Yangebup lakes throughout the sampling period. Mean TP concentrations (Fig. 3d) ranged from 22 to 92 , from 230 to $>1000$, from and 28 to $>150 \mu \mathrm{g} \mathrm{L}{ }^{-1}$ in Jackadder, Bibra and Yangebup lakes, respectively. Meanwhile, mean TDP concentrations (Fig. 3e) ranged from 12 to 24 , from 17 to 142 , and from 14 to $37 \mu \mathrm{g} \mathrm{L}{ }^{-1}$ in Jackadder, Bibra and Yangebup lakes, respectively. Temporal variation of macronutrient concentrations in Yangebup and Jackadder lakes were much smaller than in Bibra Lake. The large increase of TP, TDP, TN and TDN in Bibra Lake might again have been a concentration effect due to the lake drying up. Mean TFe and TDFe concentrations were higher in Bibra Lake during the earlier three sampling dates. Mean TFe (Fig. 3f) ranged from 77 to 247, from 147 to 220 , and from 51 to $110 \mu \mathrm{g} \mathrm{L}^{-1}$ in Jackadder, Bibra and Yangebup lakes, respectively. Mean TDFe (Fig. 3g) ranged from 24 to 174, from 61 to 117 , and from 21 to $89 \mu \mathrm{g} \mathrm{L}{ }^{-1}$ in Jackadder, Bibra and Yangebup lakes, respectively. TN (Fig. 3h) and TDN (Fig. 3i) concentrations were up to one order of magnitude higher in Bibra lakes compared to concentrations in Jackadder and Yangebup lakes. In contrast, mean TN : TP in Bibra Lake were lower than the ratios in Jackadder and Yangebup lakes (Fig. 3j). Mean TN: TP ranged from 18 to 60, 16 to 38, and 29 to 115 in Jackadder, Bibra and Yangebup lakes, respectively. $\mathrm{NH}_{4}^{+}$decreased over time in Jackadder and Yangebup lakes (Fig. 3k) and mean concentrations ranged from 43 to 170 , from 157 to 239 , and from 40 to $143 \mu \mathrm{g} \mathrm{L}{ }^{-1}$ in Jackadder, Bibra and Yangebup lakes, respectively.

The three lakes were significantly different in salinity, phosphorus, nitrogen and iron, either as total or dissolved forms (except TDFe) (ANOVA; Table 1), but did not show a significant difference in $\mathrm{pH}$, air temperature and TDFe. The post hoc tests (LSD) indicated that Jackadder and Yangebup Lake did not differ in TP, TDP and $\mathrm{NH}_{4}^{+}$; however, both lakes were different to Bibra Lake. Furthermore, all lakes were different in salinity, TN, TDN, and TFe. Jackadder and Yangebup lakes can be classified as eutrophic, while Bibra Lake can be classified as hypereutrophic, based on the mean TP concentrations (Carlson, 1977). Nitrogen-limited conditions in a lake are usually defined when the TN : TP weight ratios are less than 10 (Graham et al., 2004). As our results indicate that $\mathrm{TN}$ : TP ratios below 10 were rare, the studied lakes were not associated with persistent nitrogen limitation.

\subsection{Variability of cyanobacterial biomass and microcystin concentration}

Cyanobacterial communities in all lakes contained potentially toxin-producing cyanobacteria including Microcystis spp., Planktothrix spp., Anabaenopsis spp., Anabaena spp. and Nodularia spp. (Fig. 4) with Microcystis spp. being the most abundant cyanobacterial genera in all lakes. Mean total cyanobacterial biomass was 5.41, 29.60, $15.14 \mu \mathrm{g} \mathrm{L}^{-1}$ in Jackadder, Bibra and Yangebup Lake, re- 
Table 1. Physical and chemical properties of the three lakes throughout the sample period (January-March 2010), including analysis of differences between lakes (one-way ANOVA).

\begin{tabular}{|c|c|c|c|c|c|c|c|}
\hline \multirow[t]{2}{*}{ Factors } & \multicolumn{2}{|c|}{ Jackadder Lake $(N=18)$} & \multicolumn{2}{|c|}{ Bibra Lake $(N=12)$} & \multicolumn{2}{|c|}{ Yangebup Lake $(N=18)$} & \multirow{2}{*}{$\begin{array}{l}\text { Differences between lakes } \\
\text { (one-way ANOVA) }\end{array}$} \\
\hline & Mean \pm SD & Range & Mean \pm SD & Range & Mean \pm SD & Range & \\
\hline $\mathrm{pH}$ & $8.7 \pm 0.3$ & $8.1-9.0$ & $8.9 \pm 0.2$ & $8.5-9.2$ & $8.9 \pm 0.4$ & $7.5-9.3$ & $F_{(2,45)}=2.16$ \\
\hline Air Temp & $33.0 \pm 4.9$ & $27.4-42.7$ & $35.7 \pm 4.7$ & $30.8-43.0$ & $34.7 \pm 4.1$ & $30.8-43.0$ & $F_{(2,45)}=1.31$ \\
\hline Sal (ppk) & $0.4 \pm 0.04$ & $0.3-0.4$ & $2.9 \pm 1.0$ & $1.7-4.1$ & $0.9 \pm 0.1$ & $0.8-1.1$ & $F_{(2,45)}=99.08^{*}$ \\
\hline $\mathrm{TP}\left(\mu \mathrm{gL}^{-1}\right)$ & $44.0 \pm 28.0$ & $20.0-131.6$ & $598.1 \pm 362.0$ & $214.7-1145.9$ & $64.8 \pm 44.2$ & $24.0-168.0$ & $F_{(2,45)}=40.28^{*}$ \\
\hline $\operatorname{TDP}\left(\mu \mathrm{g} \mathrm{L}^{-1}\right)$ & $17.6 \pm 4.8$ & $12.0-26.7$ & $67.9 \pm 51.3$ & $16.0-180.0$ & $23.2 \pm 7.6$ & $13.3-40.7$ & $F_{(2,45)}=15.27^{*}$ \\
\hline $\mathrm{TFe}\left(\mu \mathrm{gL}^{-1}\right)$ & $123.3 \pm 66.2$ & $63.6-261.8$ & $192.1 \pm 43.4$ & $138.2-289.3$ & $81.5 \pm 24.1$ & $48.4-122.9$ & $F_{(2,45)}=18.91^{*}$ \\
\hline $\mathrm{TDFe}\left(\mu \mathrm{g} \mathrm{L}^{-1}\right)$ & $69.2 \pm 66.3$ & $20.0-200.0$ & $89.1 \pm 30.4$ & $38.6-154.1$ & $52.9 \pm 28.9$ & $11.2-92.6$ & $F_{(2,45)}=2.15$ \\
\hline $\mathrm{NH}_{4}\left(\mu \mathrm{g} \mathrm{L}^{-1}\right)$ & $100.8 \pm 54.9$ & $30.0-180.0$ & $191.5 \pm 33.8$ & $150.0-250.3$ & $86.3 \pm 45.6$ & $30.0-160.0$ & $F_{(2,45)}=20.04^{*}$ \\
\hline $\mathrm{TN}\left(\mathrm{mg} \mathrm{L}^{-1}\right)$ & $1.3 \pm 0.4$ & $0.7-2.2$ & $11.7 \pm 5.2$ & $4.9-17.3$ & $3.5 \pm 0.8$ & $1.9-5.2$ & $F_{(2,45)}=59.38^{*}$ \\
\hline $\mathrm{TDN}\left(\mathrm{mg} \mathrm{L}^{-1}\right)$ & $0.8 \pm 0.2$ & $0.4-1.1$ & $8.7 \pm 3.0$ & $4.9-14.0$ & $2.4 \pm 0.3$ & $1.9-2.8$ & $F_{(2,45)}=104.98^{*}$ \\
\hline $\mathrm{TN}: \mathrm{TP}$ & $35.6 \pm 14.9$ & $11.1-76.1$ & $23.1 \pm 10.0$ & $10.3-41.1$ & $68.6 \pm 29.9$ & $25.0-124.1$ & $F_{(2,45)}=19.51^{*}$ \\
\hline
\end{tabular}

$N=$ number of samples; $\mathrm{SD}=$ standard deviation; $*=p<0.05$.
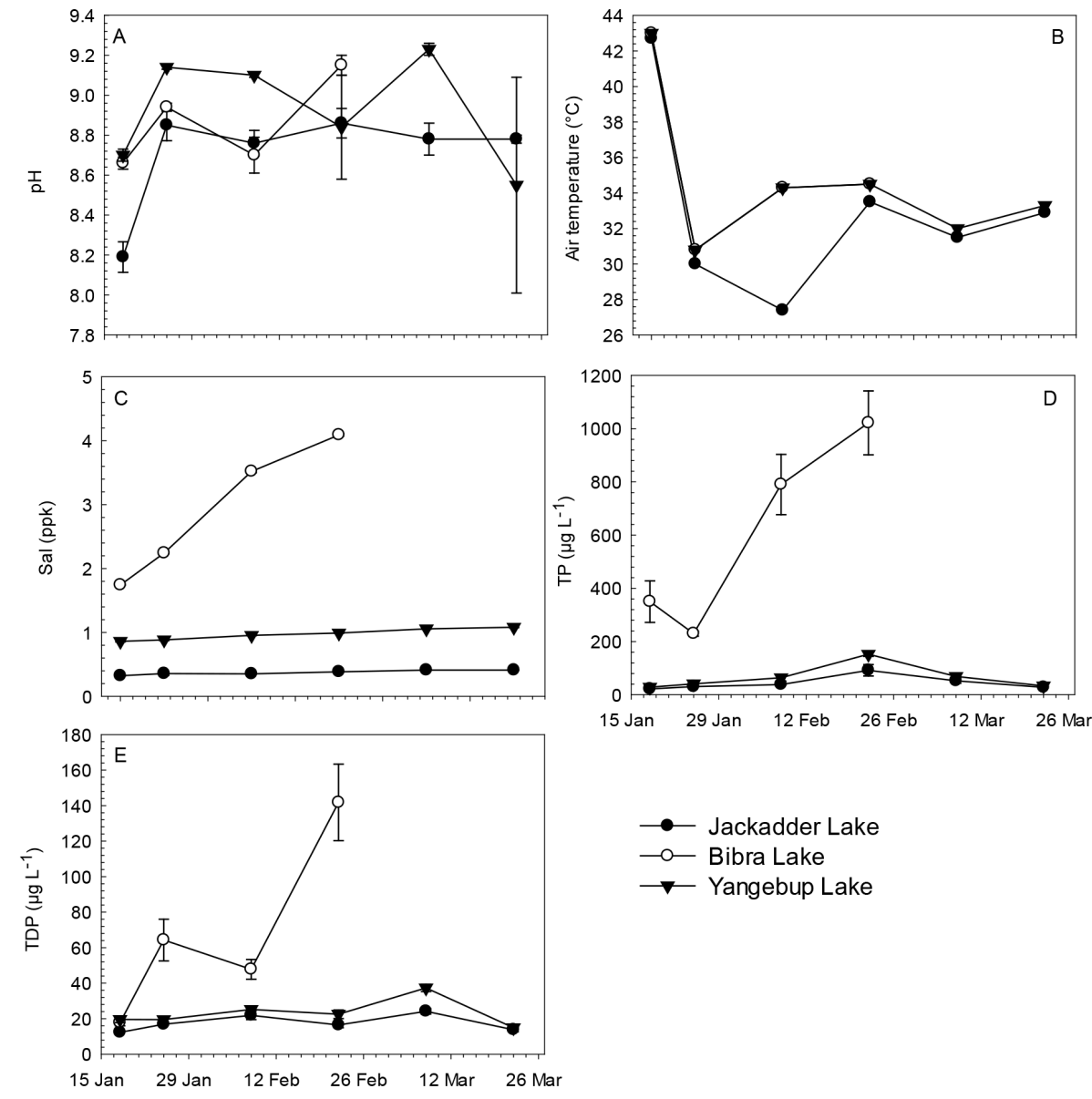

Figure 3. 

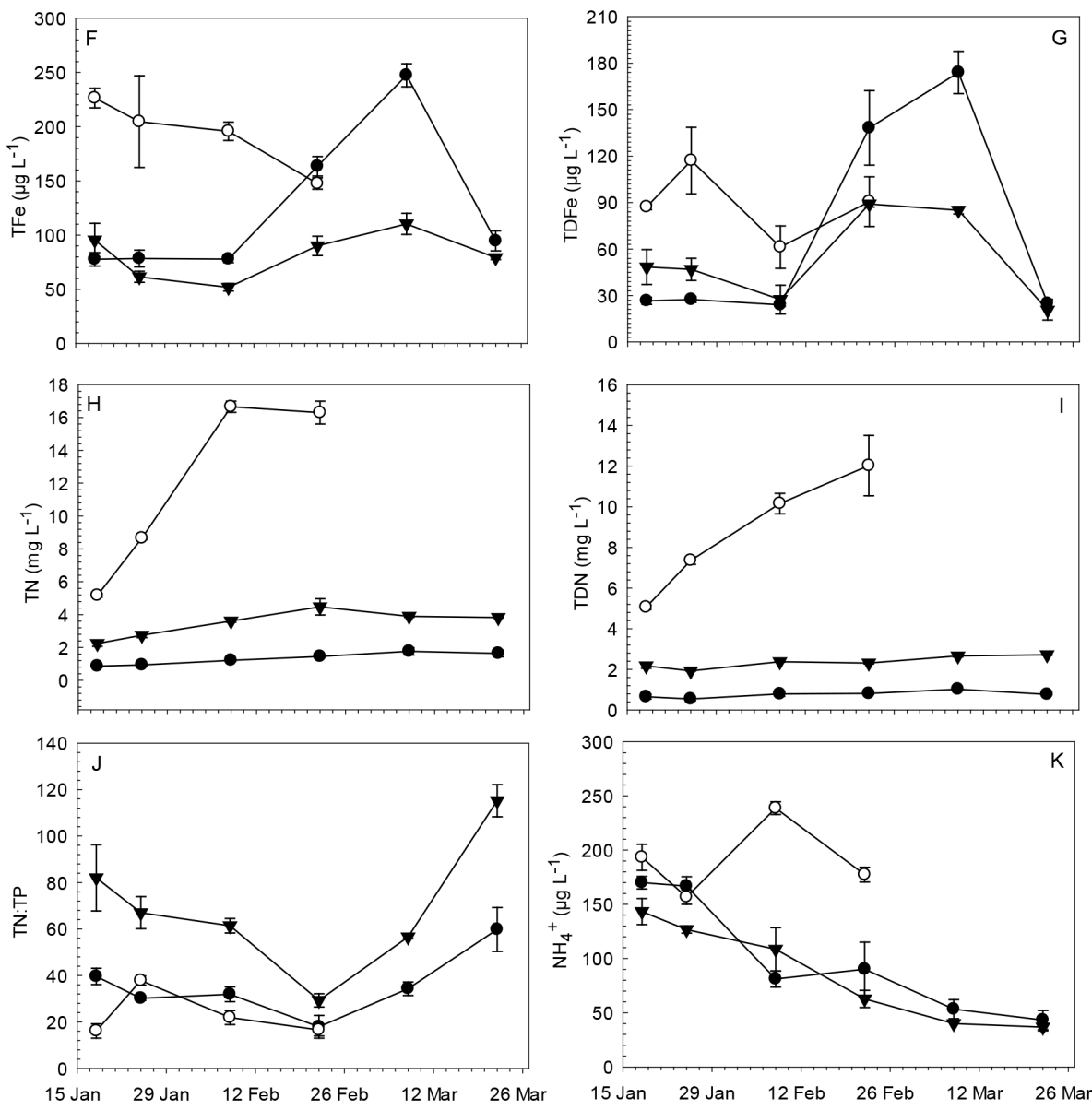

Figure 3. Mean values ( \pm one standard error) of physicochemical variables over time $(A=p H ; B=A i r ~ T e m p ; C=S a l ; D=T P ; E=T D P$; $\mathrm{F}=\mathrm{TFe} ; \mathrm{G}=\mathrm{TDFe} ; \mathrm{H}=\mathrm{TN} ; \mathrm{I}=\mathrm{TDN} ; \mathrm{J}=\mathrm{TN}$ : TP; $\mathrm{K}=\mathrm{NH}_{4}^{+}$) in Jackadder, Bibra and Yangebup lakes from January to March 2010 . The mean is calculated from the three locations per lakes.

spectively (Fig. 5a). Cyanobacterial biomass varied within an order of magnitude on a temporal basis in Bibra and Jackadder lakes (Jackadder: $1-12 \mu \mathrm{g} \mathrm{L}-1$, Bibra: 5-83 $\mu \mathrm{g} \mathrm{L}^{-1}$, Yangebup: $8-32 \mu \mathrm{g} \mathrm{L}^{-1}$ ). Although cyanobacterial biomass was significantly higher in Bibra Lake compared to the other two lakes $\left(F_{(2,45)}=7.62, p<0.05\right)$, the cyanobacterial fraction (the ratio of cyanobacterial chlorophyll $a$ to total phytoplankton chlorophyll $a$ ) in this lake was significantly lower than in Jackadder and Yangebup Lake $\left(F_{(2,45)}=3.59\right.$, $p<0.05$ ) (Fig. 5b). Cyanobacterial fraction ranged between 0.05 to 0.71 in Jackadder Lake, 0.16 to 0.68 in Yangebup Lake, and 0.11 to 0.51 in Bibra Lake. The post hoc tests indicated that Jackadder and Yangebup lakes did not differ in cyanobacterial biomass and cyanobacterial fraction, but both lakes were different to Bibra Lake.

Cellular microcystin concentration $\left(\mathrm{mgg} \mathrm{g}^{-1}\right.$ cyanobacterial dry mass) varied over 3 orders of magnitude in Jackadder Lake, and 2 orders of magnitude in both Bibra Lake and Yangebup Lake (Fig. 5c) throughout the sampling events. Mean cellular microcystin concentrations were
$0.407 \mathrm{mg} \mathrm{g}^{-1}$ in Jackadder Lake, $0.233 \mathrm{mg} \mathrm{g}^{-1}$ in Bibra Lake, and $0.150 \mathrm{mg} \mathrm{g}^{-1}$ in Yangebup Lake. Cellular microcystin concentration was not significantly different between lakes $\left(F_{(2,45)}=2.07, p>0.05\right)$. Mean extracellular microcystin fraction was 0.18 in Jackadder Lake, 0.04 in Bibra Lake, and 0.26 in Yangebup Lake (Fig. 5d). The post hoc tests indicated that Bibra Lake was the only lake that had a significantly different extracellular microcystin fraction when compared to other lakes $\left(F_{(2,45)}=6.49, p<0.05\right)$.

\subsection{Relationship between environmental factors and cyanobacterial fraction, cyanobacterial biomass, or microcystin concentration}

Most analysed nutrients were weakly but significantly correlated with cyanobacterial fraction, biomass and microcystin concentrations when data from all lakes were combined ( $\mathrm{Ta}-$ bles 2 and 3). The correlations presented in Tables 2 and 3 suggest that, in general, cyanobacterial dominance in the phytoplankton community was favoured at relatively lower nutrient concentrations as it was negatively correlated to TP, 

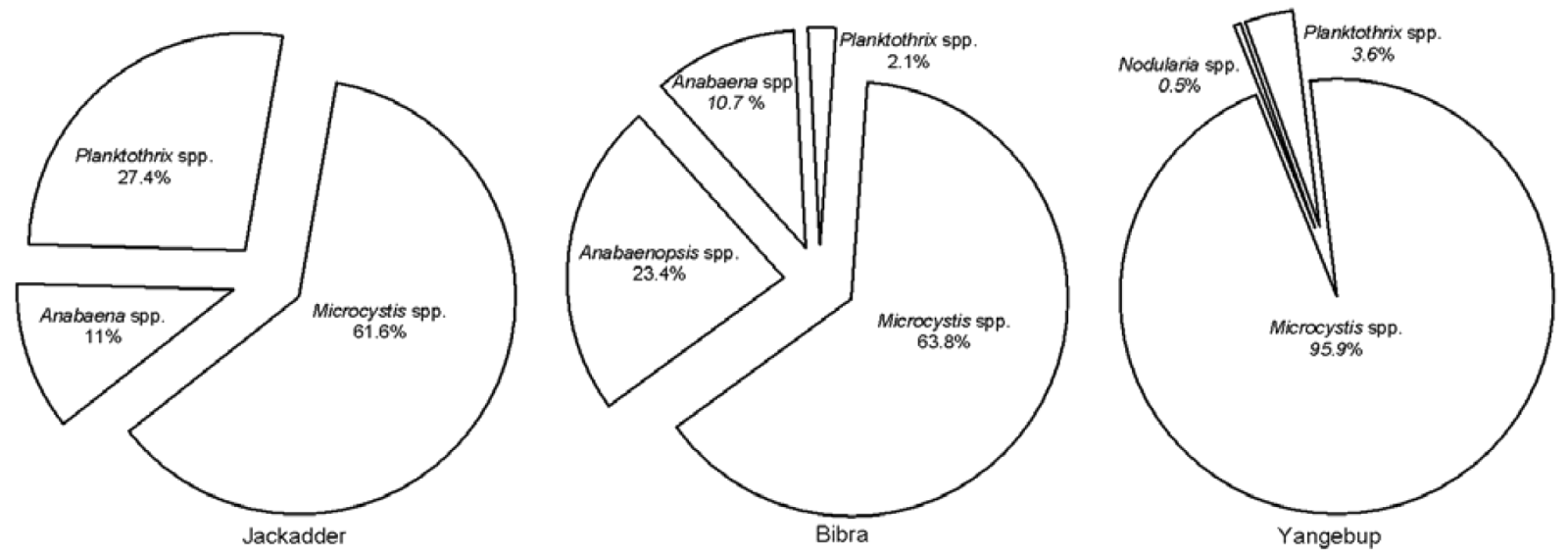

Figure 4. Mean biomass $\left(\mu \mathrm{m}^{3} \mathrm{~mL}^{-1}\right)$ proportions of potentially toxic cyanobacterial genera in Jackadder, Bibra and Yangebup lakes during the study period.
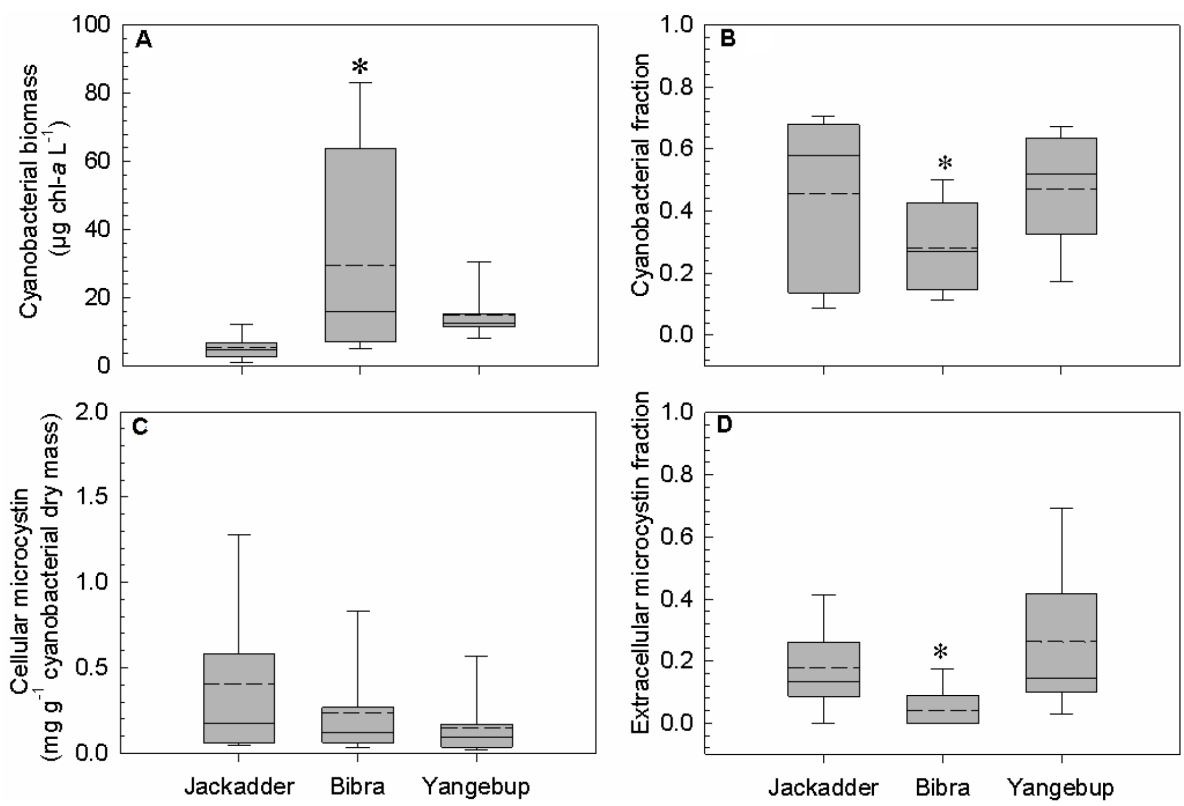

Figure 5. The variability of (a) cyanobacterial biomass ( $\left.\mu \mathrm{g} \mathrm{chl} a \mathrm{~L}^{-1}\right)$, (b) cyanobacterial fraction (cyanobacterial biomass to total biomass), (c) cellular microcystin concentration ( $\mathrm{mg} \mathrm{g}^{-1}$ cyanobacterial dry mass) and (d) extracellular microcystin fraction over time for each lake. Boxes represent 25th to 75th percentiles; straight lines within the boxes mark the median, short dashed lines the mean; whiskers below and above the boxes indicate 10 th and 90 th percentiles. Asterisks $\left(^{*}\right)$ indicate lakes that are significantly $(p<0.05)$ different from other lakes.

TDP, TFe, and TDFe. In contrast, cyanobacterial fraction was positively correlated with $\mathrm{TN}$ : TP ratio, potentially due to relatively lower TP concentrations in comparison to TN concentrations. Cyanobacterial biomass on the other hand was positively correlated to salinity, TN, TDN and $\mathrm{NH}_{4}^{+}$, but negatively correlated with TDFe. Cellular microcystin concentration was positively correlated with phosphorus and iron, but not with nitrogen. TDFe showed the strongest positive correlation with cellular microcystin concentration, followed by TP, TFe and TDP. Cellular microcystin was also negatively correlated with $\mathrm{TN}$ : $\mathrm{TP}$ ratio (Table 3 ). In contrast to cellular microcystin, extracellular microcystin fraction was negatively correlated with salinity, TP, TDP, TN, TDN, and positively correlated with TN : TP ratio (Table 3 ). Correlating environmental variables with cyanobacteria or microcystin for each lake separately, the correlations that were significant (Pearson's) were different between lakes (Tables 2 and 3).

Using data from all lakes combined in linear mixed models, cyanobacterial fraction was negatively correlated to TP, TDP, TFe, TDFe (Fig. 6a-d), and positively to TN:TP (Fig. 6e). However, within each lake, the correlations with cyanobacterial fraction were significant only for TP, TDP 

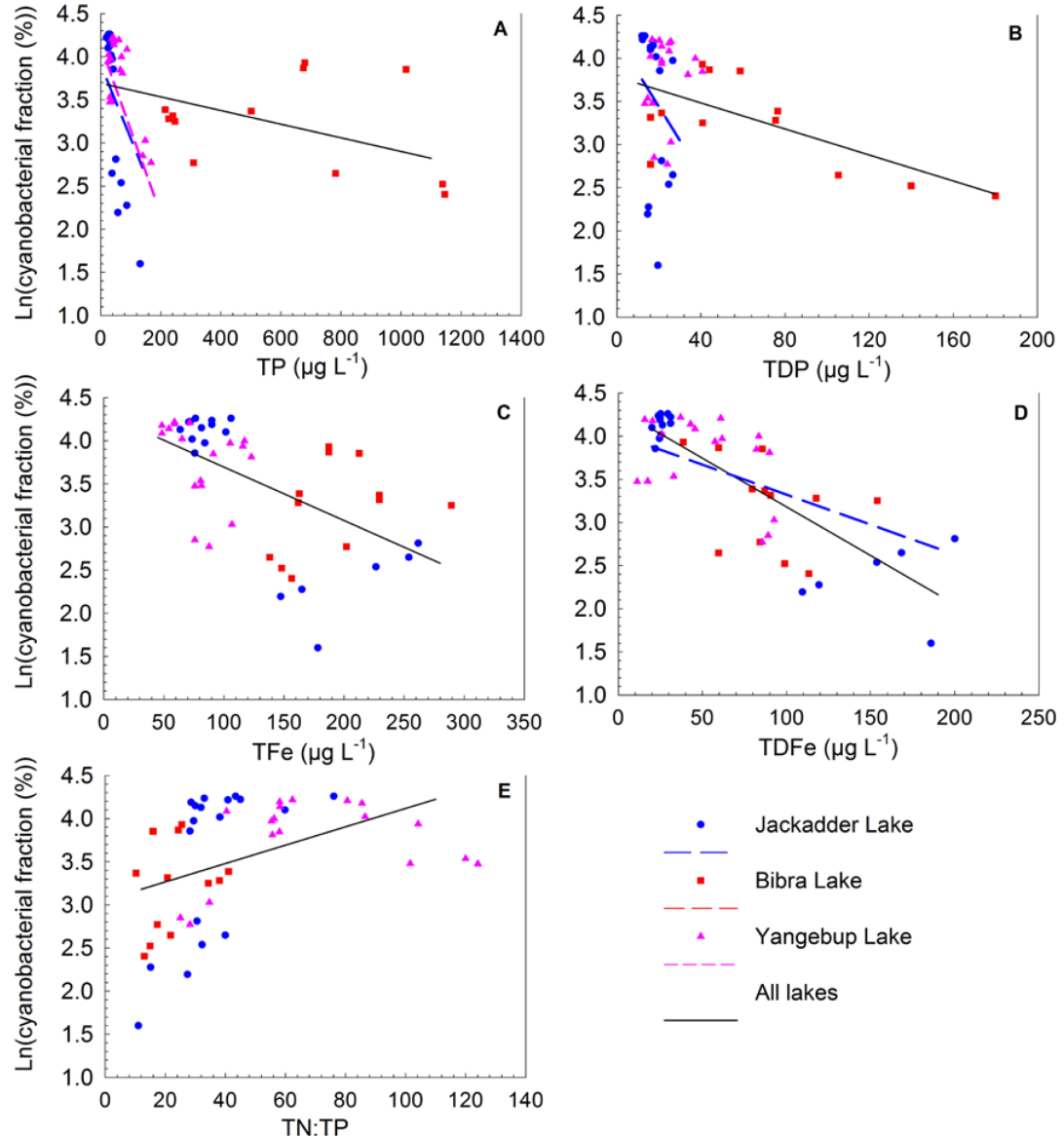

All lakes

Figure 6. The correlations between cyanobacterial fraction and (a) TP, (b) TDP, (c) TFe, (d) TDFe, (e) TN : TP in Jackadder, Bibra and Yangebup lakes during the study period. Regression curves for each individual lake were calculated by linear mixed models with site and date as random factors on data from each lake (broken lines) while all data points were combined for the overall regression using a linear mixed model adding lake as random factor (solid line). Only significant $(p<0.05)$ regressions are shown.

Table 2. Pearson's correlation coefficients $(R)$ between the environmental factors and cyanobacterial fraction (\%) or cyanobacterial biomass ( $\mu \mathrm{g} \mathrm{chl} a \mathrm{~L}^{-1}$ ) analysed for each lake and for all lakes combined using bivariate correlation analysis. The dependent variables are ln transformed.

\begin{tabular}{|c|c|c|c|c|c|c|c|c|}
\hline \multirow[b]{2}{*}{ Factor } & \multicolumn{4}{|c|}{ Cyanobacterial fraction $(\%)$} & \multicolumn{4}{|c|}{ Cyanobacterial biomass ( $\left.\mu \mathrm{g} \operatorname{chl} a \mathrm{~L}^{-1}\right)$} \\
\hline & $\begin{array}{r}\text { All lakes } \\
N=48\end{array}$ & $\begin{array}{r}\text { Jackadder } \\
N=18\end{array}$ & $\begin{array}{r}\text { Bibra } \\
N=12\end{array}$ & $\begin{array}{r}\text { Yangebup } \\
N=18\end{array}$ & $\begin{array}{r}\text { All lakes } \\
N=48\end{array}$ & $\begin{array}{r}\text { Jackadder } \\
N=18\end{array}$ & $\begin{array}{r}\text { Bibra } \\
N=12\end{array}$ & $\begin{array}{r}\text { Yangebup } \\
N=18\end{array}$ \\
\hline $\mathrm{pH}$ & -0.108 & -0.363 & -0.653 & 0.225 & 0.087 & -0.181 & -0.671 & 0.287 \\
\hline Air Temp & 0.018 & 0.119 & -0.112 & 0.016 & 0.138 & 0.002 & 0.080 & 0.043 \\
\hline Salinity & -0.250 & -0.423 & -0.204 & -0.460 & 0.454 & -0.063 & -0.038 & -0.236 \\
\hline $\mathrm{TP}$ & -0.337 & -0.873 & -0.272 & -0.742 & 0.282 & -0.808 & -0.090 & 0.092 \\
\hline TDP & -0.357 & -0397 & -0.641 & 0.147 & 0.060 & -0.320 & -0.574 & 0.406 \\
\hline $\mathrm{TFe}$ & -0.570 & -0.789 & 0.389 & -0.304 & -0.040 & -0.577 & 0.340 & -0.326 \\
\hline TDFe & -0.777 & -0.903 & -0.355 & -0.432 & -0.339 & -0.727 & -0.424 & -0.113 \\
\hline $\mathrm{NH}_{4}$ & 0.105 & 0.375 & 0.576 & 0.543 & 0.345 & 0.042 & 0.721 & 0.222 \\
\hline $\mathrm{TN}$ & -0.236 & -0.487 & 0.035 & -0.628 & 0.477 & -0.185 & 0.197 & 0.025 \\
\hline TDN & -0.265 & -0.534 & -0.219 & -0.305 & 0.430 & -0.314 & -0.078 & -0.084 \\
\hline $\mathrm{TN}: \mathrm{TP}$ & 0.423 & 0.570 & 0.299 & 0.264 & 0.164 & 0.741 & 0.145 & -0.339 \\
\hline
\end{tabular}

Significant $(p<0.05)$ correlations are highlighted in bold. 

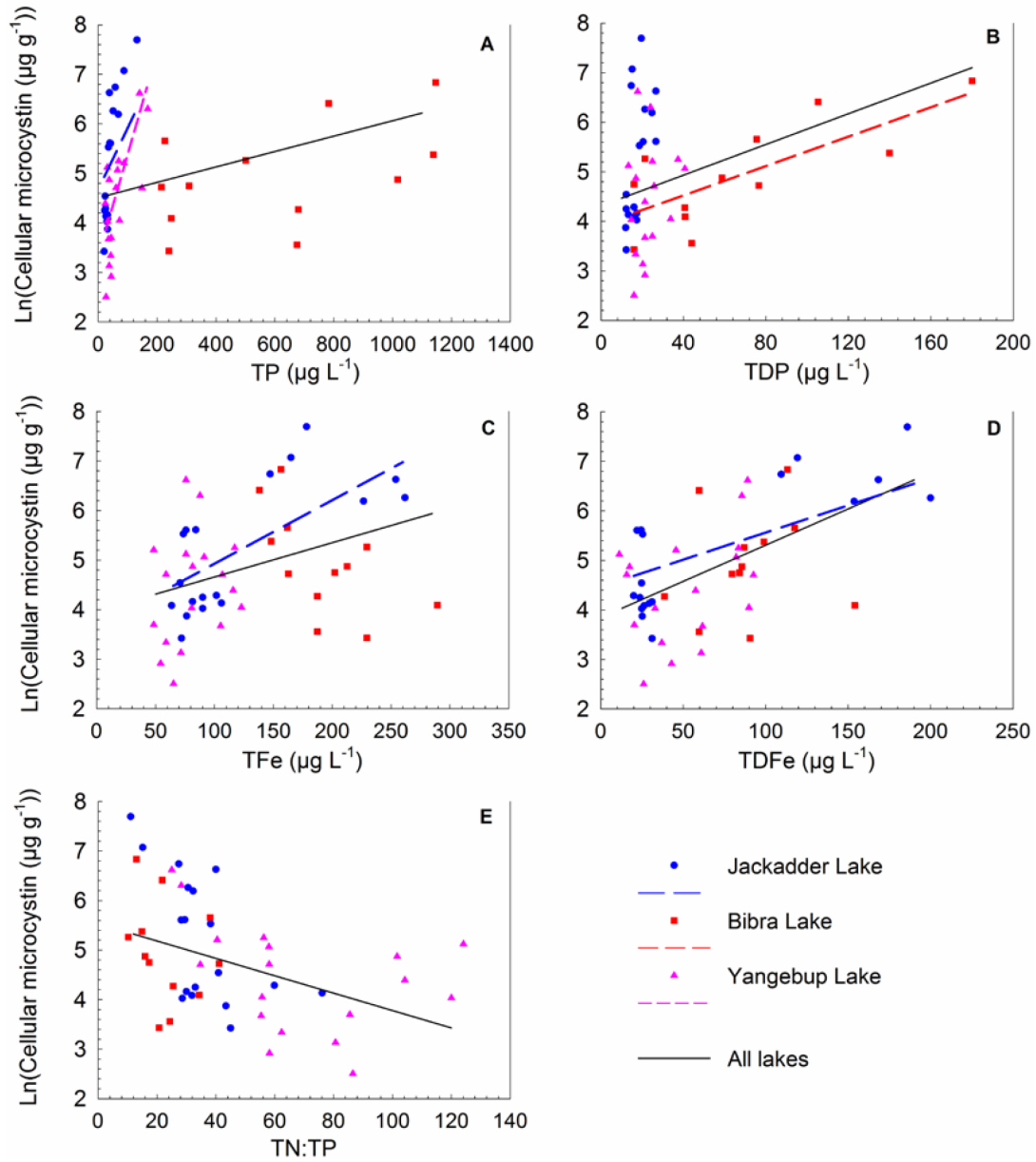

Figure 7. The correlations between cellular microcystin concentration and (a) TP, (b) TDP, (c) TFe, (d) TDFe, (e) TN : TP in Jackadder, Bibra and Yangebup lakes during the study period. Regression curves for each individual lake were calculated by linear mixed models with site and date as random factors on data from each lake (broken lines) while all data points were combined for the overall regression using a linear mixed model adding lake as random factor (solid line). All regression shown are $p<0.05$, except for the regression calculated for all lakes combined in (a), which is $p<0.1$.

and TDFe in Jackadder Lake and TP in Yangebup Lake. Cellular microcystin concentration was on the other hand positively correlated to TP, TDP, TFe and TDFe (Fig. 7ad) and negatively to TN:TP (Fig. 7e). Within each lake, these correlations were only significant for TP, TFe, TDFe in Jackadder Lake (Fig. 7a, c and d), for TDP in Bibra Lake (Fig. 7b) and for TP in Yangebup Lake (Fig. 7a). When combining all lakes, extracellular microcystin fraction was negatively correlated to salinity (linear mixed model; $p<0.1$ ), TP and TDP, but positively to TN : TP (Fig. 8a-d). Jackadder Lake was the only lake showing significant correlations between extracellular microcystin fraction and salinity (positive, Fig. 8a) and TP (negative, Fig. 8b). Using linear mixed models, cyanobacterial biomass was only significantly correlated to TDP and TDFe when combining all lakes (Fig. 8e and f), with Bibra Lake showing a significant negative correlation to TDFe (Fig. 8f). The $95 \%$ confidence intervals of the slopes of the correlations between TP and cyanobacte- rial fraction or extracellular microcystin fraction in Jackadder Lake and in all lakes combined (Figs. $6 \mathrm{a}$ and $8 \mathrm{~b}$ ) or between salinity and extracellular microcystin fraction in Jackadder Lake and in all lakes combined (Fig. 8a) did not overlap, providing a conservative estimate that the slopes were significantly different (Payton et al., 2003).

\subsection{Multivariate analysis of site-specific environmental factors and the variability of cyanobacteria and microcystin concentration}

The first RDA analysis showed significant relationships $(p<0.05)$ between the measured environmental factors and the combined variability of cyanobacterial fraction, cellular microcystin concentration and extracellular microcystin fraction for each lake. The canonical ordination indicated that $75 \%$ (Jackadder Lake; $R_{\text {adj. }}^{2}=0.75 ; F=5.726$ ), $80 \%$ (Bibra Lake; $R_{\text {adj. }}^{2}=0.80 ; F=5.888$ ) and $75 \%$ (Yange- 

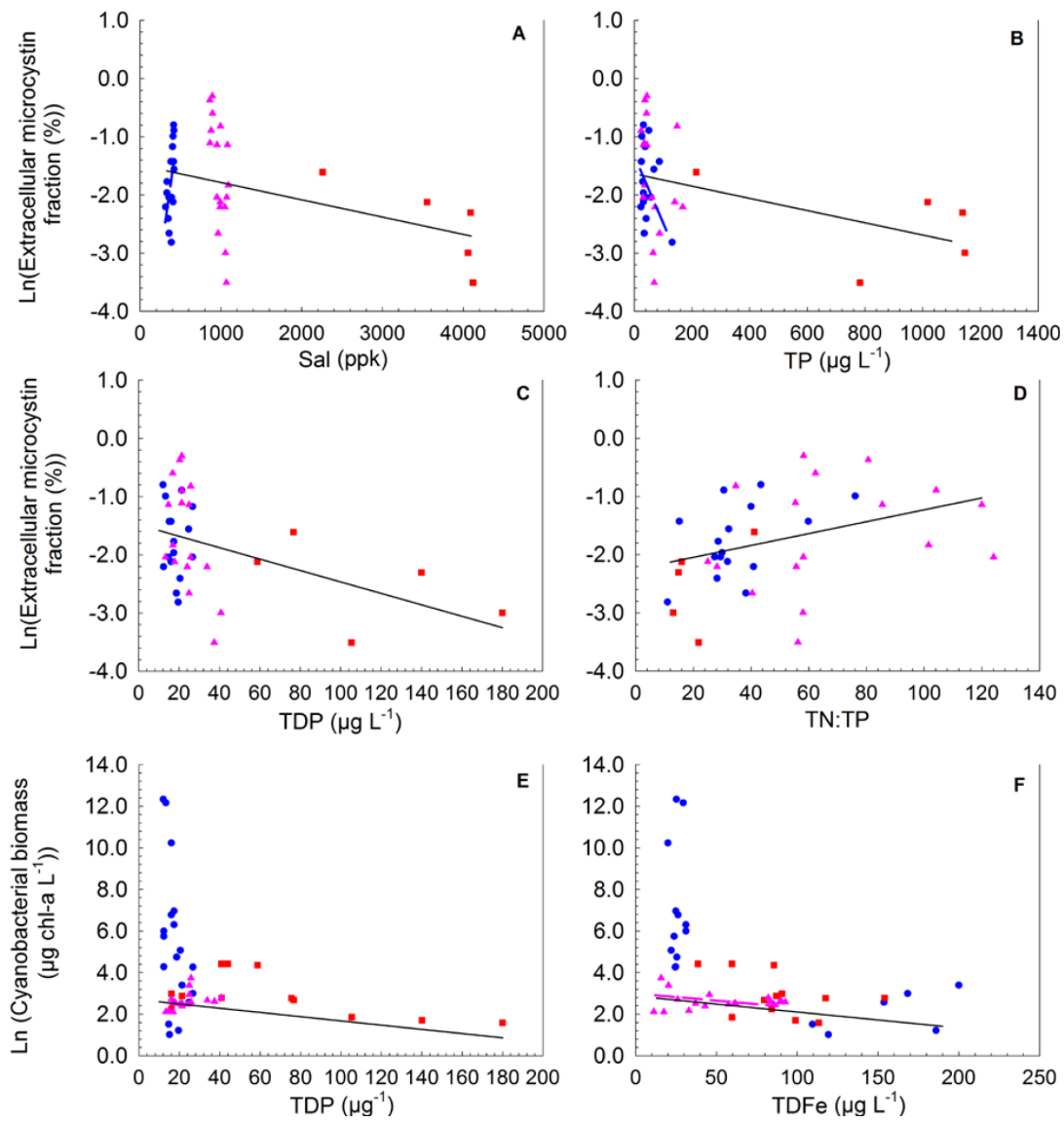

Figure 8. The correlations between extracellular microcystin fraction and (a) Sal, (b) TP, (c) TDP, (d) TN : TP, and between cyanobacterial biomass and (e) TDP, (f) TDFe in Jackadder, Bibra and Yangebup lakes during the study period. Regression curves for each individual lake were calculated by linear mixed models with site and date as random factors on data from each lake (broken lines) while all data points were combined for the overall regression using a linear mixed model adding lake as random factor (solid line). All regression shown are $p<0.05$, except for the regression calculated for all lakes combined in (a), which is $p<0.1$. Symbols and lines are explained in Fig. 6.

Table 3. Pearson's correlation coefficients $(R)$ between the environmental variables and cellular microcystin concentration $\left(\mu g^{-1}\right)$ or extracellular microcystin fraction $(\%)$ analysed for each lake and for all lakes combined using bivariate correlation analysis. The dependent variables are $\ln$ transformed. Extracellular microcystin fraction was zero in seven cases, leading to an $N=5$ only.

\begin{tabular}{|c|c|c|c|c|c|c|c|c|}
\hline \multirow[b]{2}{*}{ Factor } & \multicolumn{4}{|c|}{ Cellular microcystin concentration $\left(\mu \mathrm{g} \mathrm{g}^{-1}\right)$} & \multicolumn{4}{|c|}{ Extracellular microcystin fraction $(\%)$} \\
\hline & $\begin{array}{r}\text { All lakes } \\
N=48\end{array}$ & $\begin{array}{r}\text { Jackadder } \\
N=18\end{array}$ & $\begin{array}{r}\text { Bibra } \\
N=12\end{array}$ & $\begin{array}{r}\text { Yangebup } \\
N=18\end{array}$ & $\begin{array}{r}\text { All lakes } \\
N=38\end{array}$ & $\begin{array}{r}\text { Jackadder } \\
N=18\end{array}$ & $\begin{array}{l}\text { Bibra } \\
N=5\end{array}$ & $\begin{array}{l}\text { Yangebup } \\
\qquad N=18\end{array}$ \\
\hline $\mathrm{pH}$ & 0.227 & 0.426 & 0.762 & 0.190 & -0.297 & 0.155 & -0.714 & -0.360 \\
\hline Air Temp & -0.246 & -0.288 & -0.185 & -0.160 & 0.077 & 0.138 & -0.686 & 0.130 \\
\hline Salinity & 0.067 & 0.330 & 0.448 & 0.587 & -0.375 & 0.570 & -0.775 & -0.659 \\
\hline $\mathrm{TP}$ & 0.399 & 0.826 & 0.489 & 0.696 & -0.392 & -0.303 & -0.441 & -0.295 \\
\hline TDP & 0.296 & 0.553 & 0.764 & 0.225 & -0.428 & -0.088 & -0.498 & -0.587 \\
\hline $\mathrm{TFe}$ & 0.343 & 0.715 & -0.605 & 0.230 & -0.037 & 0.380 & 0.499 & -0.245 \\
\hline $\mathrm{TDFe}$ & 0.590 & 0.811 & 0.135 & 0.400 & -0.063 & 0.166 & 0.162 & -0.252 \\
\hline $\mathrm{NH}$ & -0.267 & -0.433 & -0.338 & -0.579 & -0.115 & -0.382 & 0.013 & 0.530 \\
\hline $\mathrm{TN}$ & 0.085 & 0.441 & 0.268 & 0.613 & -0.376 & 0.420 & -0.633 & -0.417 \\
\hline TDN & 0.095 & 0.482 & 0.533 & 0.479 & -0.400 & 0.324 & -0.921 & -0.633 \\
\hline $\mathrm{TN}: \mathrm{TP}$ & -0.446 & -0.593 & -0.257 & -0.382 & 0.386 & 0.492 & 0.514 & 0.239 \\
\hline
\end{tabular}

Significant $(p<0.05)$ correlations are highlighted in bold. 

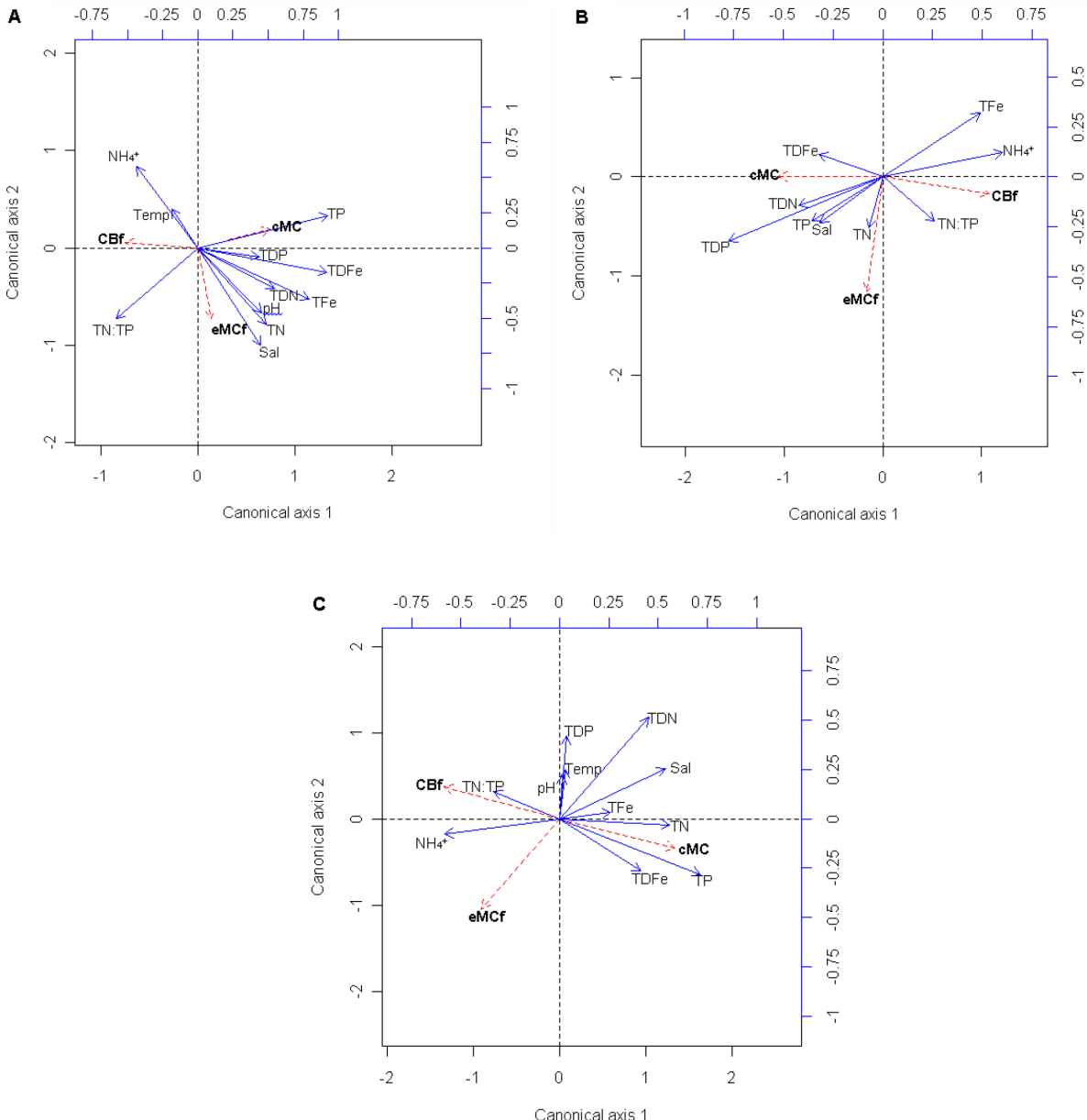

Figure 9. RDA biplots for the environmental variables and the cyanobacterial fraction (CBf), cellular microcystin (cMC) and extracellular microcystin fraction (eMCf) in (a) Jackadder Lake, (b) Bibra Lake, (c) Yangebup Lake; solid arrows indicate environmental variables; short dashed arrows indicate response variables. Canonical axes 1 and 2 represent a linear combination of the environmental variables, and axes are scaled by the square root of their eigenvalues.

bup Lake; $\left.R_{\text {adj. }}^{2}=0.75 ; F=5.804\right)$ of the combined variability of cyanobacterial fraction, cellular microcystin concentration and extracellular microcystin fraction can be explained by the measured environmental factors (Fig. 9a-c). The second RDA analysis, which sought to find relationships between environmental factors and absolute cyanobacterial biomass, cellular microcystin concentration and extracellular microcystin fraction for each lake found that $71 \%$ (Jackadder Lake; $R_{\text {adj. }}^{2}=0.71 ; F=4.725$ ), $80 \%$ (Bibra Lake; $R_{\text {adj. }}^{2}=0.80 ; F=5.806$ ) and $66 \%$ (Yangebup Lake; $R_{\text {adj. }}^{2}=0.66 ; F=3.953$ ) of the combined variability of absolute cyanobacterial biomass, cellular microcystin concentration and extracellular microcystin fraction can be explained by the measured environmental factors (Fig. 10a-c).

In both sets of analyses, many of the environmental factors that were closely correlated to cyanobacteria and microcystins were slightly different between lakes. TDP was only correlated to either cyanobacteria fraction or cellular micro- cystin concentration in Bibra and Jackadder lakes (Fig. 9a and b) but not in Yangebup Lake (Fig. 9c). Additionally, TFe was positively correlated to cyanobacteria only in Bibra Lake (Figs. 9b and 10b) but not in the other two lakes (Figs. 9a, c and $10 \mathrm{a}, \mathrm{c})$. In comparison to the other factors, TDFe was always negatively correlated to cyanobacterial fraction and biomass and positively correlated to cellular microcystin concentration variability (Figs. 9 and 10).

\section{Discussion}

The relationships between the environmental factors and cyanobacterial and microcystin variability were different between lakes. This is an indication that the relevance of factors that drive cyanobacteria and their toxin production depends on their site-specific combinations. Our results suggest that the site-specificity of environmental triggers may be related to spatial heterogeneity of the respective environmental fac- 

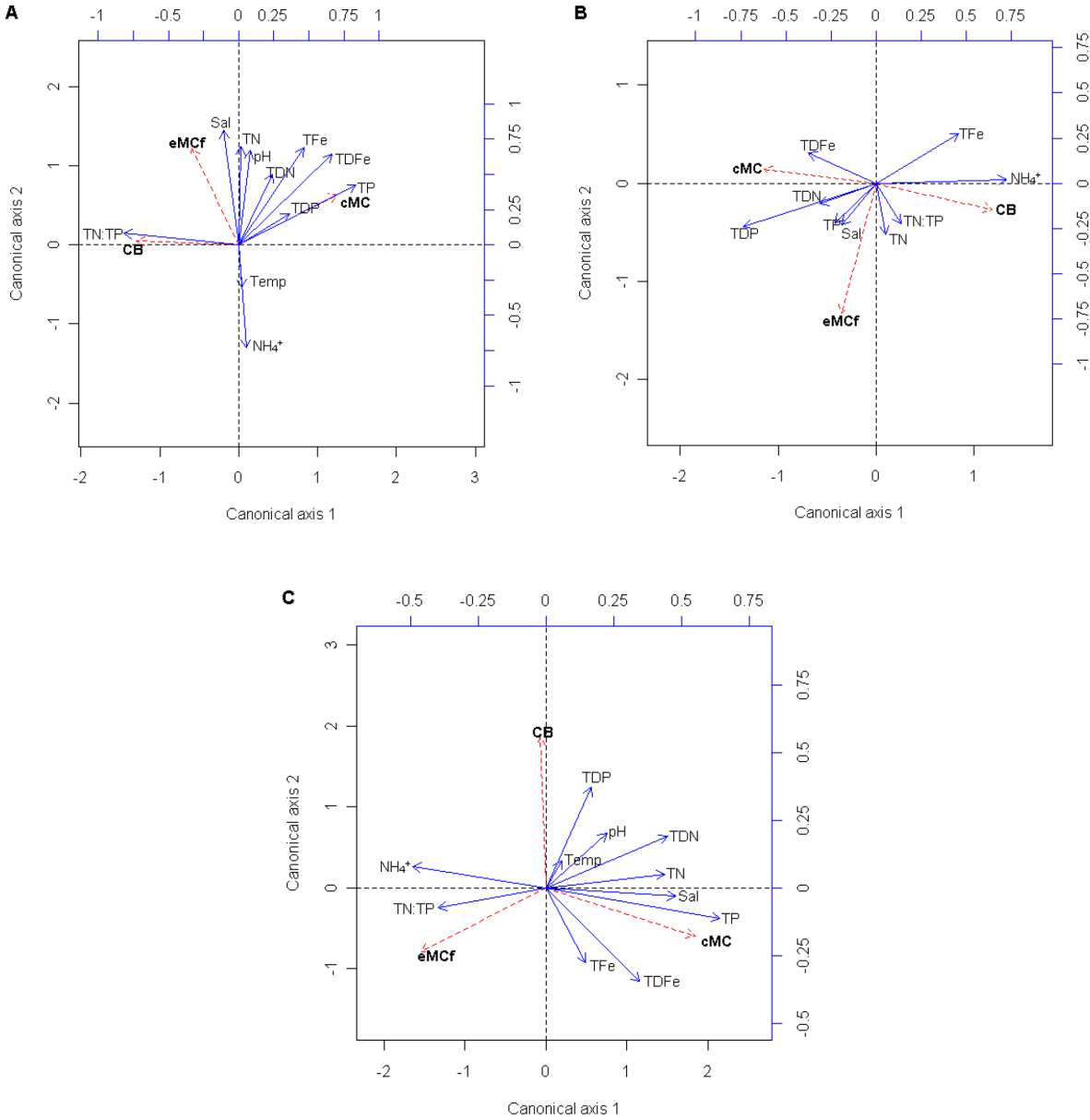

Figure 10. RDA biplots for the of environmental variables and the absolute cyanobacteria biomass (CB), cellular microcystin (cMC) and extracellular microcystin fraction (eMCf) in (a) Jackadder Lake, (b) Bibra Lake, (c) Yangebup Lake; solid arrows indicate environmental variables; short dashed arrows indicate response variables. Canonical axes 1 and 2 represent a linear combination of the environmental variables, and axes are scaled by the square root of their eigenvalues.

tor, as each factor can be present at different concentration regimes in each lake. Graham et al. (2004) and Dolman et al. (2012) have suggested that the correlations between the environmental factors and cyanobacterial biomass and microcystin concentration could change when the concentrations of the respective environmental factors increase from low to high in systems. Our results support these previous findings as the relationships between cyanobacterial fraction, cyanobacterial biomass and cellular microcystin concentration with TFe and TDFe were closely related to the concentration levels of TFe and TDFe in each lake. Mean TFe concentration in Bibra Lake was 1 order of magnitude higher than in Jackadder and Yangebup lakes, while mean TDFe concentrations in all lakes ranged within the same order of magnitude (Table 1). This could explain why the relationship between cyanobacterial fraction or cellular microcystin and $\mathrm{TFe}$ was different for between lakes, while TDFe was not. Further, the correlation between cyanobacterial fraction and TP was only significant in Yangebup and Jackadder lakes, which both had lower TP concentrations than Bibra Lake, in which no significant correlation was found. Meanwhile, the correlation between cellular microcystin concentration and TFe was negative only in Bibra Lake, where TFe was present at significantly higher concentrations compared to the other two lakes. This indicates that the effect of environmental factors on cyanobacterial and microcystin variability may depend on site-specific factors such as concentration regimes, even in non-nutrient-limited lakes. Therefore, a generalisation by only using concentrations of nutrients might not be sufficient for future management of lakes.

The site-specificity of the environmental triggers of cyanobacterial and microcystin variability may also be a consequence of the variation of cyanobacterial communities between the systems. TFe was negatively correlated to cyanobacterial fraction in Jackadder and Yangebup Lake, and positively in Bibra Lake. The cyanobacterial community in Jackadder Lake was composed of only one nitrogenfixing cyanobacterial genera (Fig. 4). In contrast, multiple 
nitrogen-fixing cyanobacterial genera were present in Bibra Lake. Nitrogen-fixing cyanobacteria are known to utilise more iron in comparison to non-nitrogen-fixers (Wilhelm, 1995). Therefore, the site-specific correlation between TFe and cyanobacterial fraction may be explained through a greater iron requirement of the cyanobacterial community in Bibra Lake, in comparison to the cyanobacterial community in Jackadder Lake.

Currently, in the absence of lake-specific information, cyanobacterial management strategies are based on knowledge derived from general trends of the relationship between environmental factors and cyanobacteria or their toxins. Our study clearly indicates that the environmental variables explaining the variability in cyanobacteria and their toxins might be lake-specific and, more importantly, that these lakespecific correlations might also be different to the correlation derived from combining all data (e.g. Figs. $6 a$ and $8 a$ and b). This strongly supports the conclusion that site-specific conditions have to be taken into account for managing lakes with cyanobacterial blooms. Due to the site-specific environmental triggers of cyanobacterial and microcystin variability, the results presented in this study are important for the management of these lakes or lakes with similar physical, chemical and biological characteristics. In this study, the cyanobacterial fraction was negatively related with TP, TDP, TFe, $\mathrm{TDFe}$, and positively correlated with $\mathrm{TN}$ : TP ratio. These relationships illustrate that in our study, cyanobacteria may dominate under lower phosphorus availability (Amano et al., 2010). Although the lakes in our study were not limited in phosphorus per se, the differences in phosphorus levels could have been responsible for the differences in the phytoplankton communities between lakes. At high concentration, phosphorus had been shown to potentially limit the ability of cyanobacteria to become dominant in the phytoplankton community, even though cyanobacteria as a group can dominate under a wide range of conditions (Chorus and Bartram, 1999; Reynolds et al., 2006). One reason for that is the higher growth rate of other phytoplankton groups compared to cyanobacteria, and, as such, their ability to utilise nutrients faster under high nutrient conditions. This can explain the negative correlation between cyanobacterial fraction and phosphorus concentration found in our study, and, maybe as a consequence of this, a positive correlation with TN : TP. In terms of iron, low availability was correlated to high cyanobacterial fraction in these lakes. This result indicated that cyanobacteria pose a competitive advantage to dominate the phytoplankton community under low iron availability. Cyanobacteria are capable to alter their cellular iron requirements, and increase the ability to utilise iron at a low concentration, through the presence of siderophores (Boyer et al., 1987; Lee et al., 2011). As reported in Nagai et al. (2007), cyanobacteria including Microcystis spp. and Planktothrix spp., can produce siderophores and become a superior competitor under iron-limited conditions. These results indicate that phosphorus and iron reduction in water bodies might not be a sufficient remedial strategy against the occurrence of toxic cyanobacterial bloom.

In contrast to cyanobacterial fraction, cellular microcystin concentration was positively related to TP, TDP, TFe, TDFe and negatively correlated to TN : TP in all lakes. High availability of phosphorus relative to other nutrients is required for energy and material supply in microcystin biosynthesis as microcystin production in cyanobacterial cells is an energyintensive process (Vezie et al., 2002). This is further supported through the observed negative relationship between cellular microcystin and TN: TP ratio, as low microcystin production is expected under conditions where phosphorus is present at lower concentrations in relation to other nutrients. In addition, the positive correlation between iron and cellular microcystin concentration is in agreement with earlier studies which suggested that iron plays an essential role in many metabolic pathways including microcystin biosynthesis in cyanobacteria (Jiang et al., 2008; Wang et al., 2010a). Our results illustrate that reducing phosphorus and iron concentrations in water bodies could potentially reduce the overall toxicity of cyanobacterial bloom, even though it might not completely prevent the occurrence of cyanobacterial bloom.

Environmental conditions influencing the release of microcystin into the environment, besides cells lyses, are not well understood (Rohrlack and Hyenstrand, 2007; Barrington et al., 2013). Our results showed that correlations exist between extracellular microcystin fraction and nutrients; however, the correlations could be direct or indirect ones. If they are direct, our results suggest that regardless of the potentially low microcystin production, cyanobacteria may release microcystins at lower nitrogen and phosphorus concentrations. This would support by the hypothesis that microcystin is involved in nutrient competition in the phytoplankton community (Huisman and Hulot, 2005).

Based on the RDA results, the measured environmental factors were able to better predict the variability of cyanobacterial fraction than the variability of absolute cyanobacterial biomass in two out of three lakes (Yangebup and Jackadder lakes). Both descriptors are important indicators for management. The competition with other phytoplankton, described by the cyanobacterial fraction in this study can affect the toxin production within a cell through allelopathy (Huisman and Hulot, 2005). Therefore, understanding the importance of site-specific drivers of both biomass and the cyanobacterial fraction is of highest importance to develop successful and sustainable management strategies.

\section{Conclusions}

The current approach to water body restoration and the prevention of toxic cyanobacterial blooms relies on reducing nutrient loading into water bodies and limiting the availability of nutrients in the water column. This approach might not always be successful in preventing the occurrence of 
cyanobacterial blooms, due to the roles of physicochemical factors on cyanobacteria and microcystin variability being dependent on the site-specific combination of environmental factors. Our study clearly highlights the importance of taking between-lake heterogeneity in the management of toxic cyanobacterial blooms into account. Site-specific studies may be required to determine the factors causing cyanobacterial dominance and microcystin production in different systems with different characteristics such as the hydrology, land use and water chemistry.

In our study, the dominance of cyanobacteria in the phytoplankton community is correlated to lower phosphorus and iron concentrations in the systems. In contrast, cyanobacteria required higher phosphorus and iron concentrations in the water column to produce a high amount of microcystin. Therefore, reducing phosphorus and iron concentration in the water column might not be a sufficient remedial strategy against the occurrence of toxic cyanobacterial bloom, if these nutrients are still available in sufficient amount to support the growth of highly competitive cyanobacteria. However, reducing phosphorus and iron could reduce the amount of microcystin being produced within cyanobacterial cells.

Acknowledgements. This project was funded by the Australian Research Council's Linkage Project funding scheme (LP0776571) and the Water Corporation of Western Australia. We wish to thank Pierre Legendre, Laura Firth and Kevin Murray for their valuable statistical advice, and Liah Coggins for her help in the editing of the paper. During the study, S. C. Sinang, was supported by a scholarship from Universiti Pendidikan Sultan Idris (UPSI) and Malaysian Government.

Edited by: C. Stamm

\section{References}

Amano, Y., Sakai, Y., Sekiya, T., Takeya, K., Taki, K., and Machida, M.: Effect of phosphorus fluctuation caused by river water dilution in eutrophic lake on competition between blue-green alga Microcystis aeruginosa and diatom Cyclotella sp, J. Environ. Sci.-China, 22, 1666-1673, 2010.

Ame, M. V. and Wunderlin, D. A.: Effects of iron, ammonium and temperature on microcystin content by a natural concentrated $\mathrm{Mi}$ crocystis aeruginosa population, Water Air Soil Poll., 168, 235248, 2005.

APHA: Standard methods for the examination of water and wastewater, 20th Edn., edited by: Clesceri, L. S., Greenberg, A. E., and Eaton, A. D., American Public Health Association, Washington DC, 1998.

Arnold, J.: Perth Wetlands Resource Book, Environmental Protection Authority, Perth, 1990.

Arnold, T. N. and Oldham, C. E.: Trace-element contamination of a shallow wetland in Western Australia, Mar. Freshwater Res., 48, 531-539, 1997.
Barrington, D. J., Ghadouani, A., and Ivey, G. N.: Cyanobacterial and microcystins dynamics following the application of hydrogen peroxide to waste stabilisation ponds, Hydrol. Earth Syst. Sci., 17, 2097-2105, doi:10.5194/hess-17-2097-2013, 2013.

Beutler, M., Wiltshire, K. H., Meyer, B., Moldaenke, C., Luring, C., Meyerhofer, M., Hansen, U. P., and Dau, H.: A fluorometric method for the differentiation of algal populations in vivo and in situ, Photosynth. Res., 72, 39-53, 2002.

Boyer, G. L., Gillam, A. H., and Trick, C.: Iron chelation and uptake, in: The Cyanobacteria, edited by: Fay, P., and Baalen, C. V., Elsevier Science Publishers, the Netherlands, 415-431, 1987.

Bureau of Meteorology: Climate Data Online, http://www.bom.gov. au/climate/data/?ref=ftr (last access: 1 Sepember 2014), 2014.

Carey, C. C., Weathers, K. C., Ewing, H. A., Greer, M. L., and Cottingham, K. L.: Spatial and temporal variability in recruitment of the cyanobacterium Gloeotrichia echinulata in an oligotrophic lake, Freshwater Sci., 33, 577-592, doi:10.1086/675734, 2014.

Carlson, R. E.: A trophic state index for lakes, Limnol. Oceanogr., 22, 361-369, 1977.

Chaffin, J. D. and Bridgeman, T. B.: Organic and inorganic nitrogen utilization by nitrogen-stressed cyanobacteria during bloom conditions, J. Appl. Phycol., 26, 299-309, doi:10.1007/s10811013-0118-0, 2014.

Chorus, I. and Bartram, J.: Toxic cyanobacteria in water: A guide to their public health consequences, monitoring and management, E \& FN Spon, London and New York, 1999.

Davis, J. A., Rosich, R. S., Bradley, J. S., Growns, J. E., Schmidt, L. G., and Cheal, F.: Wetland classification on the basis of water quality and invertebrate community data, R/N:0730952487, Water Authority of Western Australia, Perth, 1993.

Davis, T. W., Berry, D. L., Boyer, G. L., and Gobler, C. J.: The effects of temperature and nutrients on the growth and dynamics of toxic and non-toxic strains of Microcystis during cyanobacteria blooms, Harmful Algae, 8, 715-725, 2009.

Department of Planning: Stirling City Centre District Water Management Strateg, Stirling City Centre District Water Management Strategy, Perth, 2010.

Dolman, A., Rucker, J., Pick, F., Fastner, J., Rohrlack, T., Mischke, U., and Wiedner, C.: Cyanobacteria and cyanotoxins: The influence of nitrogen versus phosphorus, PLoS ONE, 7, e38757, doi:10.1371/journal.pone.0038757, 2012.

Dunlop, M.: Yangebup lake environmental management study, Perth, Prepared for City of Cockburn, ENV Australia Pty Ltd, Perth, 2008.

Eisentraeger, A., Dott, W., Klein, J., and Hahn, S.: Comparative studies on algal toxicity testing using fluorometric microplate and Erlenmeyer flask growth-inhibition assays, Ecotox. Environ. Safe, 54, 346-354, 2003.

Engström-Öst, J., Repka, S., Brutemark, A., and Nieminen, A.: Clay- and algae-induced effects on biomass, cell size and toxin concentration of a brackish-water cyanobacterium, Hydrobiologia, 714, 85-92, doi:10.1007/s10750-013-1523-8, 2013.

Environmental Protection Authority: Drainage Management in South Jandakot and Beeliar Wetlands, EPA Bulletin, 371, 1989.

Eva, P. and Lindsay, B.: Microcystin and algal chlorophyll in relation to nearshore nutrient concentrations in Lake Winnipeg, Canada, Environ. Pollut., 3, 36-47, 2014.

Geis, S. W., Fleming, K. L., Korthals, E. T., Searle, G., Reynolds, L., and Karner, D. A.: Modifications to the algal growth inhibition 
test for use as a regulatory assay, Environ. Toxicol. Chem., 19, 36-41, 2000.

Ghadouani, A. and Smith, R. E. H.: Phytoplankton distribution in Lake Erie as assessed by a new in situ spectrofluorometric technique, J. Great Lakes Res., 31, 154-167, 2005.

Graham, J. L., Jones, J. R., Jones, S. B., Downing, J. A., and Clevenger, T. E.: Environmental factors influencing microcystin distribution and concentration in the Midwestern United States, Water Res., 38, 4395-4404, 2004.

Harada, K., Kondo, F., and Lawton, L. A.: Laboratory analysis of cyanotoxins, in: Toxic cyanobacteria in water: A guide to their public health consequences, monitoring and management, edited by: Chorus, I. and Bartram, J., E \& FN Spon, London, New York, 363-367, 1999.

Hillebrand, H., Durselen, C., Kirschtel, D., Pollingher, U., and Zohary, T.: Biovolume calculation for pelagic and benthic microalgae, J. Phycol., 35, 403-424, 1999.

Huisman, J. and Hulot, F. D.: Population dynamic of harmful cyanobacteria, in: Harmful cyanobacteria, edited by: Huisman, J., Matthijs, H. C. P., and Visser, P. M., Springer, the Netherlands, 143-176, 2005.

Jang, M. H., Ha, K., Jung, J. M., Lee, Y. J., and Takamura, N.: Increased microcystin production of Microcystis aeruginosa by indirect exposure of nontoxic cyanobacteria: Potential role in the development of Microcystis bloom, B. Environ. Contam. Tox., 76, 957-962, 2006.

Jiang, Y., Ji, B., Wong, R. N. S., and Wong, M. H.: Statistical study on the effects of environmental factors on the growth and microcystins production of bloom-forming cyanobacterium Microcystis aeruginosa, Harmful Algae, 7, 127-136, 2008.

Kemp, A. S.: Freshwater cyanoprokaryota blooms in the Swan Coastal plain wetlands: Ecology, taxonomy and toxicology, $\mathrm{PhD}$ thesis, Department of Environmental Biology, Curtin University of Technology, Perth, 2009.

Komarek, J. and Hauer, T.: On-line database of cyanobacterial genera, http://www.cyanodb.cz (last access: 14 August 2011), 2011.

Koreiviene, J., Anne, O., Kasperoviciene, J., and Burskyte, V.: Cyanotoxin management and human health risk mitigation in recreational waters, Environ. Monit. Assess., 186, 4443-4459, doi:10.1007/s10661-014-3710-0, 2014.

Lawton, L. A., Edwards, C., and Codd, G. A.: Extraction and highperformance liquid chromatographic method for the determination of microcystins in raw and treated waters, Analyst, 119, 1525-1530, 1994.

Lee, W., van Baalen, M., and Jansen, V. A. A.: An evolutionary mechanism for diversity in siderophore-producing bacteria, Ecol. Lett., 15, 119-125, 2011.

Lehman, P. W., Marr, K., Boyer, G. L., Acuna, S., and Teh, S. J.: Long-term trends and causal factors associated with Microcystis abundance and toxicity in San Francisco Estuary and implications for climate change impacts, Hydrobiologia, 718, 141-158, doi:10.1007/s10750-013-1612-8, 2013.

Lei, L., Peng, L., Huang, X., and Han, B.-P.: Occurrence and dominance of Cylindrospermopsis raciborskii and dissolved cylindrospermopsin in urban reservoirs used for drinking water supply, South China, Environ. Monit. Assess., 186, 3079-3090, doi:10.1007/s10661-013-3602-8, 2014.

Lewis, W. M. and Wurtsbaugh, W. A.: Control of lacustrine phytoplankton by nutrients: Erosion of the phosphorus paradigm,
Int. Rev. Hydrobiol., 93, 446-465, doi:10.1002/iroh.200811065, 2008.

Li, D., Yu, Y., Yang, Z., Kong, F., Zhang, T., and Tang, S.: The dynamics of toxic and nontoxic Microcystis during bloom in the large shallow lake, Lake Taihu, China, Environ. Monit. Assess., 186, 3053-3062, doi:10.1007/s10661-013-3600-x, 2014.

Liu, Y.: Dynamic evaluation on ecosystem service values of urban rivers and lakes: A case study of Nanchang City, China, Aquat. Ecosyst. Health, 17, 161-170, doi:10.1080/14634988.2014.907223, 2014.

Meriluoto, J, and Codd, G.: Toxic-cyanobacterial monitoring and cyanotoxin analysis, in: Acta Academiae Aboensis Ser. B, Mathematica et physica, edited by: Högnäs, G., Åbo Akademi University Press, Åbo, 2005.

Nagai, T., Imai, A., Matsushige, K., and Fukushima, T.: Growth characteristics and growth modeling of Microcystis aeruginosa and Planktothrix agardhii under iron limitation, Limnology, 8, 261-270, 2007.

O'Bannon, C., Carr, J., Seekell, D. A., and D'Odorico, P.: Globalization of agricultural pollution due to international trade, Hydrol. Earth Syst. Sc., 18, 503-510, doi:10.5194/hess-18-5032014, 2014.

Paerl, H. W. and Otten, T. G.: Harmful cyanobacterial blooms: Causes, consequences, and controls, Microb. Ecol., 65, 9951010, doi:10.1007/s00248-012-0159-y, 2013.

Payton, M. E., Greenstone, M. H., and Schenker, N.: Overlapping confidence intervals or standard error intervals: What do they mean in terms of statistical significance?, , 3, 1-6, 2003.

Pineda-Mendoza, R. M., Olvera-Ramirez, R., and MartinezJeronimo, F.: Microcystins produced by filamentous cyanobacteria in urban lakes. A case study in Mexico City, Hidrobiologica, 22, 290-298, 2012.

Rastogi, R. P., Sinha, R. P., and Incharoensakdi, A.: The cyanotoxinmicrocystins: current overview, Rev. Environ. Sci. Bio-Technol., 13, 215-249, doi:10.1007/s11157-014-9334-6, 2014.

Reichwaldt, E. S., Song, H., and Ghadouani, A.: Effects of the distribution of a toxic Microcystis bloom on the small scale patchiness of zooplankton, PLoS ONE, 8, 66674, doi:10.1371/journal.pone.0066674, 2013.

Reichwaldt, E. S. and Ghadouani, A.: Effects of rainfall patterns on toxic cyanobacterial blooms in a changing climate: Between simplistic scenarios and complex dynamics, Water Res., 46, 1372 1393, doi:10.1016/j.watres.2011.11.052, 2012.

Reynolds, C. S., Usher, M., Saunders, D., Dobson, A., Peet, R., Adam, P., Birks, H. J. B., Gustafssor, L., McNelly, J., Paine, R. T., and Richardson, D.: Growth and replication of phytoplankton, in: The ecology of phytoplankton, Cambridge University Press, 178-238, 2006.

Rohrlack, T. and Hyenstrand, P.: Fate of intracellular microcystins in the cyanobacterium Microcystis aeruginosa (Chroococcales, Cyanophyceae), Phycologia, 46, 277-283, 2007.

Rolland, D. C., Bourget, S., Warren, A., Laurion, I., and Vincent, W. F.: Extreme variability of cyanobacterial blooms in an urban drinking water supply, J. Plankton Res., 35, 744-758, doi:10.1093/plankt/fbt042, 2013.

Ruiz, M., Galanti, L., Laura Ruibal, A., Ines Rodriguez, M., and Alberto Wunderlin, D.: First report of microcystins and anatoxina co-occurrence in San Roque Reservoir (Cordoba, Argentina), Water Air Soil Poll., 224, 1593-1593, 2013. 
Schindler, D.: The dilemma of controlling cultural eutrophication of lakes, P. Roy. Soc. B, 279, 4322-4333, 2012.

Sinang, S., Reichwaldt, E., and Ghadouani, A.: Spatial and temporal variability in the relationship between cyanobacterial biomass and microcystins, Environ. Monit. Assess., 185, 6379-6395, 2013.

Sitoki, L., Kurmayer, R., and Rott, E.: Spatial variation of phytoplankton composition, biovolume, and resulting microcystin concentrations in the Nyanza Gulf (Lake Victoria, Kenya), Hydrobiologia, 691, 109-122, 2012.

Smith, V. H.: Low nitrogen to phosphorus ratios favor dominace by blue-green algae in lake phytoplankton, Science, 221, 669-671, 1983.

Song, H., Coggins, L. X., Reichwaldt, E. S., and Ghadouani, A.: The importance of lake sediments as a pathway for microcystin dynamics in shallow eutrophic lakes, Toxins, 7, 900-918, 2015.

Srivastava, A., Choi, G.-G., Ahn, C.-Y., Oh, H.-M., Ravi, A., and Asthana, R.: Dynamics of microcystin production and quantification of potentially toxigenic Microcystis sp. using real-time PCR, Water Res., 46, 817-827, 2012.

Strategen: Bibra Lake: Landscape, recreational and environmental management plan, Perth, Prepared for City of Cockburn, Glenwood Nomineed Pty Ltd, Perth, 2009.

Sun, F., Yang, Z., and Huang, Z.: Challenges and solutions of urban hydrology in Beijing, Water Resour. Manage., 28, 3377-3389, doi:10.1007/s11269-014-0697-9, 2014.

Thi Thuy, D., Jaehnichen, S., Thi Phuong Quynh, L., Cuong Tu, H., Trung Kien, H., Trung Kien, N., Thi Nguyet, V., and Dinh Kim, D.: The occurrence of cyanobacteria and microcystins in the Hoan Kiem Lake and the Nui Coc reservoir (North Vietnam), Environ. Earth Sci., 71, 2419-2427, doi:10.1007/s12665013-2642-2, 2014.

Tonk, L., Bosch, K., Visser, P. M., and Huisman, J.: Salt tolerance of the harmful cyanobacterium Microcystis aeruginosa, Aquat. Microb. Ecol., 46, 117-123, 2007.

Utermöhl, H.: Zur vervollkommnung der quantitativen phytoplankton-methodik, Mitt. Int. Ver. Theor. Angew. Limnol., 9, 1-38, 1958.

Van de Waal, D. B., Smith, V. H., Declerck, S. A. J., Stam, E. C. M., and Elser, J. J.: Stoichiometric regulation of phytoplankton toxins, Ecol. Lett., 17, 736-742, doi:10.1111/ele.12280, 2014.
Vezie, C., Rapala, J., Vaitomaa, J., Seitsonen, J., and Sivonen, K.: Effect of nitrogen and phosphorus on growth of toxic and nontoxic Microcystis strains and on intracellular microcystin concentrations, Microb. Ecol., 43, 443-454, 2002.

Waajen, G. W. A. M., Faassen, E. J., and Lürling, M.: Eutrophic urban ponds suffer from cyanobacterial blooms:Dutch examples, Environ. Sci. Pollut. Res., 21, 9983-9994, 2014.

Wang, C., Kong, H.-N., Wang, X.-Z., Wu, H.-D., Lin, Y., and He, S.-B.: Effects of iron on growth and intracellular chemical contents of Microcystis aeruginosa, Biomed. Environ. Sci., 23, 4852, 2010a.

Wang, Q., Niu, Y. A., Xie, P., Chen, J., Ma, Z. M., Tao, M., Qi, M., Wu, L. Y., and Guo, L. G.: Factors affecting temporal and spatial variations of microcystins in Gonghu Bay of Lake Taihu, with potential risk of microcystin contamination to human health, Thes Scient. World J., 10, 1795-1809, 2010b.

Wilhelm, S.: Ecology of iron-limited cyanobacteria: A review of physiological responses and implications for aquatic systems, Aquat. Microb. Ecol., 9, 295-303, 1995.

Woodward, B.: Literature and Interview Project: Constructed Lakes in the Perth Metropolitan and South West Region, Perth, Prepared for Department of Water, Western Australian Local Government Association, Perth, 2008.

Yan, D. H., Wang, G., Wang, H., and Qin, T. L.: Assessing ecological land use and water demand of river systems: a case study in Luanhe River, North China, Hydrol. Earth Syst. Sci., 16, 2469 2483, doi:10.5194/hess-16-2469-2012, 2012.

Yen, H., Lin, T., Tseng, I., Tung, S., and Hsu, M.: Correlating 2MIB and microcystin concentrations with environmental parameters in two reservoirs in South Taiwan, Water Sci. Technol., 55, 33-41, 2007.

Zhang, T., Zeng, W. H., Wang, S. R., and Ni, Z. K.: Temporal and spatial changes of water quality and management strategies of Dianchi Lake in southwest China, Hydrol. Earth Syst. Sci., 18, 1493-1502, doi:10.5194/hess-18-1493-2014, 2014. 